\title{
COMMENTS
}

\section{DATE OF VALUATION IN EMINENT DOMAIN: IRREVERENCE FOR UNCONSTITUTIONAL PRACTICE*}

\author{
Donald W. Glaves†
}

Since World War II, "urban redevelopment," "turnpike," and "jet" have become household words in the United States. Government, both national and local, is engaged as never before in rebuilding cities and providing for new and more modern means of transportation. The common requirement of these activities is land which is presently private property but which must be taken by the government in furtherance of these objectives.

Suddenly, we have been thrust into a tremendous increase in both the quantity and the quality of land needed for public projects. We have the urban renewal program; slum clearance projects, which cover entire areas; the Interstate Highway System; limited access expressways; jet airport facilities; increased military needs; and new school sites which are necessary to meet the needs of our population explosion. All of these require the condemnation of more land, more valuable land, and more highly developed land, than ever before. ${ }^{1}$

It is generally agreed that use of the power of eminent domain is the only "just" means to obtain the land necessary for desired improvements. ${ }^{2}$ Prior to

* The original draft of this article was written in connection with an Urban Renewal Seminar at the University of Chicago Law School. The author is indebted to Professor Allison Dunham, Mr. Julian Levi and members of the class for their aid, sometimes unknown to them, in sharpening some of the author's ideas. Of course any criticism which might be incurred is not shared.

$\dagger$ Member of the Illinois Bar.

1 Black, Fair Market Value and Just Compensation, Technical Valuation, Oct. 1960, pp. 37, 37-38. See also, Kratovil \& Harrison, Eminent Domain-Policy and Concept, 42 CALIF. L. REv. 596, 597-98 (1954); Rosenwald, Eminent Domain in Missouri, 15 Mo. B.J. 94 (1959); Comment by Julian Levi, 25 U. CHr. L. REV. 355 (1958). For an excellent study of the entire field of urban renewal see Note, Urban Renewal: Problems of Eliminating and Preventing Urban Deterioration, 72 HARv. L. REv. 504 (1959). "[T] he indications already are that lawyers of the next generation will be even more concerned with the competition and coordination of private rights and public values in urban land; the metropolitan area is increasingly the most pressing American domestic problem." HAAR, LAND-UsE PLANNING vii-viii (1959).

2 What is not so clear, and sometimes not recognized, is the impact of an exercise of the police power on the use of eminent domain. See generally, Dunham, $A$ Legal and Economic Basis for City Planning, 58 Colum. L. REv. 650 (1958); Whyte, Development Rights (1958) (mimeo; preliminary draft of an article, on file in the University of Chicago Law Library). 
the exercise of this power on such a grand scale the courts held that there were two limitations on its use: the taking must be for a "public use"3 and "just compensation" must be made. The public use limitation, however, has fared badly in recent years. ${ }^{4}$ Indeed, Berman $v$. Parker $^{5}$ may have marked its demise. "It is within the power of the legislature to determine that the community should be beautiful as well as healthy, spacious as well as clean, wellbalanced as well as carefully patrolled.... [T] [ Amendment that stands in the way."6 State courts have been no more chary of limiting their powers of review.7 Thus, property owners are no longer able to prevent their property from being taken. They are relegated to reliance on the requirement of "just compensation"; and the courts have been reluctant to abdicate responsibility for enforcing this requirement. 8 The fifth amendment limitation on the use of eminent domain is a commonplace: "nor shall private property be taken for a public use, without just compensation." However, despite the apparent simplicity and lucidity of the requirement, the determination of compensation in a particular case only points up the inherent conflict between society and the individual. This comment will analyze the interpretations given the mandate of "just compensation," with particular reference to date of valuation and the relevance of a rise or fall in market

3 See, e.g., Nichols, The Meaning of Public Use in the Law of Eminent Domain, 20 B.U.L. Rev. 615 (1940); 2 Nichols, The LaW of EMment DomaIN $\$ \$ 7.1-7.32$ (3d ed. 1950) (hereinafter cited as Nichols).

4 See Comment, The Public Use Limitation on Eminent Domain: An Advance Requiem, 58 YALE L.J. 599 (1949); Note, supra note 1, 72 HARV. L. REv. at 517-19; Dunham, Griggs v. Allegheny County in Perspective: Thirty Years of Supreme Court Expropriation Law, 1962 Sur. CT. Rev. 63, 65.

5348 U.S. 26 (1954). See HAAR, op. cit. supra note 1, at vii: " 'Regard of the law for private property,' wrote Blackstone, 'is so great ... that it will not authorize the least violation of it, not even for the general good of the whole community;' and in the eighteenth century, the elder Pitt declaimed that 'the poorest man in his cottage could defy the Kingstorms may enter; the rain may enter-but the King of England cannot enter.' In sharp contrast, the United States Supreme Court, by upholding in sweeping terms urban redevelopment legislation, has ruled in effect that the King not only may enter, but may remain, in the name of the general good, indeed for the very purpose of keeping the rain out."

6 Berman v. Parker, supra note 5 , at 33.

7 E.g., Zurn v. City of Chicago, 389 IIl. 114, 59 N.E.2d 18 (1945); Worcester Knitting Realty Co. v. Worcester Housing Authority, 335 Mass. 19, 138 N.E.2d 356 (1956); Wilson v. City of Long Branch, 27 N.J. 360, 142 A.2d 837 (1958); Grisante v. City of Cleveland, 181 N.E.2d 299 (Ohio App. 1962); Oliver v. City of Clairton, 374 Pa. 333, 98 A.2d 47 (1953). See Krasnowiecki \& Paul, The Preservation of Open Space in Metropolitan Areas, 110 U. PA. L. Rev. 179, 202-05 (1961).

8 "The Constitution has declared that just compensation shall be paid, and the ascertainment of that is a judicial inquiry." Monongahela Nav. Co. v. United States, 148 U.S. 312, 327 (1893). See also State ex rel. Willey v. Griggs, 80 Ariz. 70, 358 P.2d 174 (1960); Opelousas, G. \& N.E. Ry. v. Saint Landry Cotton Oil Co., 118 La. 292, 42 So. 940 (1907). But see United States v. Cors, 337 U.S. 325 (1949); Benedict v. City of New York, 98 Fed. 789 (2d Cir. 1899). See Note, Change in Constitutional Doctrine Through Legislation: Some Recent Developments, 63 HARV. L. REV. 861 (1950). 
price due to government activity prior to that date. It may be wise to note here that there are few issues so likely to generate heat rather than light as the question of the proper line between the realm of the state and that of private property. 9

The supply of land is not limitless, as the increased concern with urban renewal, city planning and open spaces attests. The sudden large impact of government intervention in the consumer market has two different effects. One is direct and immediate: Government competes with other consumers for property in general, but once a parcel is designated for condemnation other potential customers are effectively eliminated, thereby freezing or depressing the current market price. Only if property owners attempt to reap the benefits of the proposed improvement, or speculate as to what the government will pay, will the market value increase. The other effect is indirect and in futuro: The ultimate public improvement will increase vicinal property values and generally decrease the supply of available land. In other words, the short-run effect of large-scale government acquisition of private property will sometimes be depressing on property values, while in the long-run the effect will usually be to increase the value of other property, sometimes to a great extent.10

Because large-scale condemnation has these effects, a determination of compensation that is "just" to the individual and to society11 is rendered extremely difficult. A particular valuation date will effectively determine where the burdens and benefits of the market effects will fall. If designation of property for condemnation depresses the market value of the property, who should assume the loss? A value date subsequent to designation will place the loss on the individual owner; conversely, the owner will benefit if speculation causes the value to rise. Similarly, if property is benefitted by a public improvement, and government at a later date condemns the benefitted property, to whom should the market value increase inure? If the valuation date is subsequent to the original improvement, the property owner will realize the rise in value. Choice of a date for valuation purposes will thus determine significant questions of social policy; realization of this is an important and perhaps deciding factor in any solution to the problem. Mr. Justice Holmes effectively stated the focus of this comment: "We are in danger of forgetting that a strong public desire to improve the public condition is not enough to warrant

${ }^{9}$ This is a paraphrase of the opening sentence of Kurland, Of Church and State and the Supreme Court, 29 U. CHr. L. REv. 1 (1961).

10 Compare Slonim, Injustices of Eminent Domain, 25 Appraisal J. 421 (1957), with Walther, Effect of Jet Airports on Market Value of Vicinage Real Estate, 27 APPRAISAL J. 465 (1959), and Balfour, America's Highway Problems and Their Likely Effect on Real Estate Markets, 22 ApPraISAL J. 497 (1954).

11 "IIt is the duty of the State, in the conduct of the inquest by which the compensation is ascertained, to see that it is just, not merely to the individual whose property is taken, but to the public which is to pay for it." Searl v. School Dist., 133 U.S. 553, 562 (1890). See also United States v. One Parcel of Land, 131 F. Supp. 443, 445 (D.D.C. 1955). 
achieving the desire by a shorter cut than the constitutional way of paying for the change."12

\section{What Is Market Value?}

\section{A. Elements of Market Value}

"By the great weight of authority,"13 the means used by the courts to attain the ultimate objective of just compensation is the standard of market value at the date of taking. Market value is "the amount of money which a purchaser willing but not obliged to buy the property would pay to an owner willing but not obliged to sell it, taking into consideration all uses to which the land was adapted and might in reason be applied."14 Various elements influence the market value of land:15 location, income-producing ability, use value. These elements in combination will determine the demand for a particular piece of property and, in conjunction with the available land supply, its price in the market place. Generally these factors will be considered in eminent domain proceedings to the same extent that they would influence a private market transaction.

For example, evidence of sales of similar property is the common vehicle for determining location value. Such evidence is admissible in most states, limited by the requirement that the property be comparable to the subject property in use and location, and that the sale be recent enough to show a similarity in the market.16 Complications arise in determining the incomeproducing ability of the property. One of the large areas of governmental activity in eminent domain is slum clearance. The "real" value of a slum building is questionable, 17 but because of the large number of tenants, the high rental value per room, and the almost total lack of improvements, slumownership is a highly lucrative business. 18 The "market value" is thus greatly enhanced by usually illegal conditions. To say that a condemning authority must pay market value for such property, when that value is given by the very condition sought to be remedied, is patently contrary to common sense.

12 Pennsylvania Coal Co. v. Mahon, 260 U.S. 393, 416 (1922). See Kratovil \& Harrison, supra note 1 , at 597 .

134 Nichols $\$ 12.1[6]$ (4th ed. 1962).

14 Id. at $\$ 12.2[1]$.

15 See Note, Valuation in Eminent Domain Proceedings in Pennsylvania, 66 Drck. L. REv. 453 (1962).

16 See 4 Nichols, \$12.311; Forest Preserve Dist. v. Lehman Estate, Inc., 388 IIl. 416, 429, 58 N.E.2d 538, 544 (1944): "The admissibility of proof of sales depends upon the similarity of the property sold and not upon the use for which the property was purchased."

17 See Levi, Impact of Law and Code Enforcement on Value, 29 APPRAISAL, J. 78 (1961), for illustrations of the dramatic downward effect of code enforcement on violators' building values.

18 Seiligman, The Enduring Slums, Fortune, Dec., 1957, p. 144. Johnson, Acquisition Appraisals for Urban Renewal, 29 APPRAISAL J. 221, 222 (1961), gives the following analysis: 
Yet, in some states, evidence to show illegal use is inadmissible. ${ }^{19} \mathrm{~A}$ few cases admit evidence to show that a building is uninhabitable; 20 in other states statutes have remedied the situation. ${ }^{21}$ In determining use value evidence is not limited to present use. The attempt is to determine the "highest and best" use of the subject property.22 Courts will consider the value of the property for other uses if it can be shown that the owner did contemplate a different use, if that use reasonably and probably would be pursued on the subject property,23 and if such other use is permitted by the building code and zoning ordinance. 24 Thus, "highest and best" use approximates the considerations that a private purchaser of the property would make. 25

Market value is not a universal standard. In some instances, because of the nature of the property involved, such as a church or a school, it will not be applied. Such property is seldom bought and sold in the market place, and thus can have no market value. A court will still inquire, however, what another religious or educational organization would pay for the property, "Blighted areas are often inhabited by minority groups. If these groups are crowded together
into a 'ghetto,' a free market no longer exists. This is the only area available to these people.
The result is that the price of property is bid up far beyond comparable property in other
neighborhoods."

${ }^{19}$ See Note, supra note 1, 72 Harv. L. Rev., at 523-25.

20 See, e.g., Hance v. State Roads Comm'n, 221 Md. 164, 156 A.2d 644 (1959); Note, Condemnation of Slum Land-Illegal Use as a Factor Reducing Valuation, 14 U. CHI. L. REv. 232 (1947). Cf. Kaperonis v. State Highway Comm'n, 251 Ia. 39, 40, 99 N.W.2d 284, 284-85 (1959): "It is well known that there are no slums in Iowa. Yet it must be admitted that the property with which we are concerned in the instant case, if located elsewhere, would not have been entirely out of place in such a district." The court held admissible evidence of uninhabitability of buildings on the condemned property.

21 IrL. Rev. Stat., ch. 47, $\$ 9.5$ (1959); New YoRk Consol. LAws ANN., Book 44A, art. $7, \S 125.4(3)$ (1955).

22 Nichols, at $\$ \S 12.3142-12.3143$. $C f$. United States v. Virginia Elec. Co., 365 U.S. 624 (1961); United States v. Twin City Power Co., 350 U.S. 222 (1956); Blas v. United States, 261 F.2d 636 (9th Cir. 1958). See Highland, Legal Aspects of Highest and Best Use Value, 24 Appraisal J. 33 (1956).

23 See, e.g., Olson v. United States, 292 U.S. 246 (1934); United States v. Cooper, 277 F.2d 857 (5th Cir. 1960); People v. La Macchia, 41 Cal. 2d 738, 264 P.2d 15 (1953); People v. Schultz Co., 123 Cal. App. 2d 925, 268 P.2d 117 (1954); Forest Preserve Dist. v. Lehman Estate, Inc., 388 III. 416, 58 N.E.2d 538 (1944).

24 Some courts apply the "Texas rule," which holds admissible evidence of a reasonable probability that rezoning in the near future will allow a more valuable use. See, e.g., Board of Comm'rs v. Tallahassee Bank \& Trust Co., 116 So. 2d 762 (Fla. 1959); Valley Stream Lawns, Inc. v. State, 9 App. Div. 2d 149, 192 N.Y.S.2d 805 (1959); City of Austin v. Cannizzo, 153 Tex. 324, 267 S.W.2d 808 (1954). An existent zoning ordinance, however, is not usually subject to collateral attack in an eminent domain proceeding on grounds of unreasonableness. Congressional School of Aeronautics, Inc. v. State Roads Comm'n, 218 Md. 236, 146 A.2d 558 (1958). But see Board of Comm'rs v. Tallahassee Bank \& Trust Co., 108 So. $2 d 74$ (Fla. App. 1958).

2s Heintz v. State, 32 Misc. 2d 1025, 226 N.Y.S.2d 540 (Ct. Cl. 1962). 
thereby indicating the strength of judicial adhesion to market value as the basic measure of compensation. 26

But, even in a situation where the property involved is bought and sold freely, the market value standard needs qualification. Indeed, if the term were used literally, the power of eminent domain would be unnecessary and superfluous, since a condemning authority could enter the land market and compete with other purchasers for the desired property. In a sale between private parties, the value to the vendor (supplier) and the necessity of the purchaser assume great importance. Yet neither aspect is completely within the judicial definition of the market value that the condemnor must pay and the condemnee must accept. Loss to the owner, as opposed to value to the condemnor, is the basic criterion of market value for the purposes of eminent domain. 27 But such loss does not include, for example, compensation for personal or sentimental value, loss of good will or inability to realize a valuable business opportunity. These losses are only "incidentally" realized, and not compensable. ${ }^{28}$ Compensable loss, as Mr. Justice Frankfurter, speaking for the Court in Kimball Laundry Co. v. United States, 29 pointed out, is an impersonal quantity.

For purposes of the compensation due under the Fifth Amendment, of course, only that "value" need be considered which is attached to "property," but that only approaches by one step the problem of definition. The value of property springs from subjective needs and attitudes; its value to the owner may therefore differ widely from its value to the taker. Most things, however, have a general demand which gives them a value transferable from one owner to another. As opposed to such personal and variant standards as value to the particular owner whose property has been taken, this transferable value has an external validity which makes it a fair measure of public obligation to compensate the loss incurred by an owner as a result of the taking of his property for public use. In view, however, of the liability of all property to condemnation for the common good, loss to the owner of nontransferable values deriving from his unique need for property or idiosyncratic attachment to it, like loss due to an exercise of the police power, is properly treated as part of the burden of common citizenship. 30

264 NichoLs, at $\$ 12.32$; United States v. 190.71 Acres of Land, 300 F.2d 52 (7th Cir. 1962).

27 United States v. Chandler-Dunbar Water Power Co., 229 U.S. 53 (1913); Chamber of Commerce v. City of Boston, 217 U.S. 189 (1910).

28 United States ex rel. TVA v. Powelson, 319 U.S. 266 (1943); Mitchell v. United States, 267 U.S. 341 (1925). See Comment, Eminent Domain Valuations in an Age of Redevelopment: Incidental Losses, 67 YALE L.J. 61 (1957).

29338 U.S. 1 (1949).

${ }^{30} \mathrm{Id}$. at 5. See Monongahela Nav. Co. v. United States, 148 U.S. 312, 326 (1893). 
From the "demand" side of the market value standard, value to the condemnor should be excluded.31 The gain that accrues or may accrue to the taker is "wholly unrelated to the deprivation imposed upon the owner. ..."32 Thus, any strategic or "hold-up" value of the property is excluded; otherwise, the last parcel of property acquired for a public improvement would be worth much more to the condemnor, and the owner would be in a position to thwart completion of the project until his demands were met.33 Also, unless there is a "reasonable probability" that the property in private hands would be put to the use for which it is taken, the purpose of the condemnation is not evidence of the property's highest and best use. ${ }^{34}$ Similarly, the effect of the condemnor's demand for the property to be taken should not be considered in ascertaining market value;"35 in other words, "owners of condemned property should not be permitted to profit by the taking, even if one concedes the social wisdom of permitting property owners to make profits in ordinary, voluntary sales." 36

\section{B. Date of Taking}

The factors that influence market value constitute just one of two major elements of the standard of eminent domain compensation. The other major element, the one with which this comment is particularly concerned, is the

31 See Hale, Value to the Taker in Condemnation Cases, 31 Colum. L. Rev. 1 (1931), for an exhaustive treatment. See also, 1 Bonbrighr, VAlUATION OF PROPERTY ch. XVI (1937).

32 Kimball Laundry Co. v. United States, 338 U.S. 1, 5 (1949).

${ }^{33}$ See, e.g., Seaboard Air Line Ry. v. United States, 261 U.S. 299 (1923); United States v. Chandler-Dunbar Water Power Co., 229 U.S. 53 (1913). Cf. Saint Clair Housing Authority v. Quirin, 379 Ill. 52, 39 N.E.2d 363 (1942); State v. Willey, 351 S.W.2d 900 (Tex. Civ. App. 1961). In County of Los Angeles v. Faus, 304 P.2d 257, 265 (Cal. App. 1956), the court said: "Nor may a jury consider the peculiarly dire need of the condemning agency for acquiring the property. In other words, the last parcel condemned for use as a roadway between two cities has no greater market value merely because it is the last link in the chain and thereby must be acquired by the condemning body."

34 United States v. Twin City Power Co., 350 U.S. 222 (1956); Olson v. United States, 292 U.S. 246 (1934); United States v. Cooper, 277 F.2d 857 (5th Cir. 1960). Compare United States v. Virginia Elec. Power Co., 365 U.S. 624 (1961); State Highway Comm'n v. Arnold, 218 Ore. 43, 341 P.2d 1089, modified on motion to reconsider, 218 Ore. 43, 343 P.2d 1113 (1959).

35 United States v. Cors, 337 U.S. 325 (1949); United States v. 158.76 Acres of Land, 298 F.2d 559 (2d Cir. 1962); Augusta Power Co. v. United States, 278 F.2d 1, 4 n.5 (5th Cir. 1960) ("The United States must be excluded as a possible assignee in determining the value of the easement, because the value of the easement must not be enhanced by the special need which the Government has for it. The Government should not, in fairness, be required to pay a value created by itself."); United States v. Rayno, 136 F:2d 376 (1st Cir. 1943); State Highway Comm'n v. Arnold, 218 Ore. 43, 341 P.2d 1089, modified on motion to reconsider, 218 Ore. 43, 343 P.2d 1113 (1959).

361 BONBRIGHT, op. cit. supra note 31 , at 409. 
date on which market value is determined. 37 This valuation date is commonly referred to as the "date of taking." It is variously designated among jurisdictions, usually by the courts but sometimes by the legislature, as the date the petition for condemnation is filed, 38 date of issuance of summons, 39 time of trial, 40 date of the deposit of assessed damages, 41 final decree of condemnation, ${ }^{42}$ or date of possession by the condemnor ${ }^{43}$ if that is prior to the state's usual date of valuation. Actually, a "taking" of property is not complete until entry of final judgment in the condemnation proceeding, when title passes from the condemnee to the condemnor. 44 Since valuation must be made prior to the judgment, an earlier, constructive, date of taking is designated.45 Whichever date is chosen, market value on that date is, as Professor Bon-

37 "The value of real estate is by no means constant, and before compensation can be intelligently assessed for the taking of land by eminent domain, a point of time must be fixed as of which the property is to be valued; and it is the value at that time which the owner is entitled to receive, even if the value of the land rises or fails before the money is actually paid to him. Upon this proposition all are agreed, but there is a great diversity of opinion as to just when that point of time occurs." 2 Nichols at 17-18 (3d ed. 1950). Professor Bonbright maintains that the time of taking "corresponds roughly, at least, to the time when the owner is deprived of the beneficial use of the property. . . "1 BONBRIGRT, op. cit. supra note 31, at 414. Compare Washington v. United States, 214 F.2d 33, 47 (9th Cir. 1954): "A condemnation case involves a taking, as of a certain date, and the case is tried with the eyes of the court and jury fastened to the date of taking, and some short but reasonable period before or after the taking."

38 South Park Comm'rs v. Dunlevy, 91 IIl. 49 (1878); 20 N.J.S.A. ch. 1-9 (1940, as amended 1953) (date of "commencement" of the action); 46 Stat. 1421 (1932), 40 U.S.C. $\$ 258 \mathrm{a}$ (1958) (date of filing the declaration of taking). Compare Illinois Cities Water Co. v. City of Mount Vernon, 11 Ill. 2d 547, 144 N.E.2d 729 (1957). In Park Dist. v. Downey Coal Co., 1 IIl. 2d 54, 115 N.E.2d 223 (1953), the Illinois Supreme Court said that the title does not actually vest in the condemnor until payment of the award; it then relates back to the date of filing the petition of condemnation.

39 Dong v. Arizona ex rel. Willey, 90 Ariz. 148, 367 P.2d 202 (1961); People v. Murata, 55 Cal. 2d 1, 9 Cal. Rptr. 601 , 357 P.2d 833 (1961); Calif. Crv. Proc. Code § 1249 (1959).

40 Williams v. City \& County of Denver, 363 P.2d 171 (Colo. 1961). Cf. Cala. Crv. Proc. CODE $\$ 1249$ (1959).

41 City of St. Louis v. International Harvester Co., 350 S.W.2d 782 (Mo. 1961); City of Dallas v. Shackelford, 200 S.W.2d 869 (Tex. Civ. App. 1946).

42 City of Long Beach v. Aistrup, 164 Cal. App. 2d 41, 330 P.2d 282 (1958).

43 United States v. Dow, 357 U.S. 17 (1958); City of Long Beach v. Aistrup, 164 Cal. App. 2d 41, 330 P.2d 282 (1958). Compare White v. State Highway Comm'n, 201 Va. 885, 114 S.E.2d 614 (1960), in which the court held that the date of entry into possession (1943) did not control since the entry was not made under color of legal title; the result was that the date of valuation was held to be in 1958, when the state finally instituted condemnation proceedings to rectify the previous error. Whether the state believed it was acting under color of title or whether it believed that it was "taking" private property, however, is an unsatisfactory analytical tool; in either case, the owner is deprived of the use of his property as of the date of entry into possession. In accord with White is Koerber v. City of New Orleans, 228 La. 903, 84 So. 2d 454 (1955).

44 Park Dist. v. Downey Coal Co., 1 Ill. 2d 54, 115 N.E.2d 223 (1953).

45 Parks v. City of Boston, 32 Mass. (15 Pick.) 198 (1834). This theory is significant in abandonment cases. See note 115 infra. 
bright pointed out, a hypothetical value. 46 Once a piece of property is "taken," the market value for its previous use is gone; all that remains is "the fact that its ownership confers a claim to a money compensation from the condemnor." 47 Indeed, once a piece of property is labeled for possible condemnation, it acquires characteristics that it previously did not have.

It seems justifiable to designate three significant points of time in eminent domain. The first occurs with a discussion of the feasibility of a public improvement and probable areas for its location. The second is when the final decision is made to go ahead with the improvement on a particular location. The third is the condemnation proceeding itself. In an urban renewal situation the first and second stages may coalesce, since redevelopment usually starts with a finding that a particular area is "blighted." Here, there will be only two recognizable stages. 48 The time lapse between each stage will vary with the nature and extent of the project, statutory requirements, attempted negotiation with condemnees, and administrative and legal delays. A delay of five years between the first and last stages is not uncommon, and in many instances the time lapse is much more startling. 49

Contemplation of government acquisition will affect property values differently depending from which stage the effect is viewed. Between the first and second stages, when it is known only that the improvement is probable but neither its precise neighborhood location nor what parcels of property will be taken, the general trend of property values in the probable area should be upward. This is true since no one can be sure that his property will not be benefitted rather than taken, and the speculative instinct is at work. $50 \mathrm{Be}$ tween the second and third stages, or in an urban renewal situation between the first and last stages, after the projected improvement's location is fixed the effect on values will be twofold. The value of property not to be taken will continue to rise, probably at a faster rate, because of the certainty that benefits from the improvement will be realized. 51 Conversely, the property

461 BoNBRIGHT, op. cit. supra note 31 , at 414 .

47 Ibid.

48 See the statutes collected in Guandolo, Housing Codes in Urban Renewal, 25 GEo. WASH. L. REV. 1, 50-51 (1956).

49 See, e.g., Williams v. City \& County of Denver, 363 P.2d 171 (Colo., 1961) (11 years); Eckhoff v. Forest Preserve Dist., 377 Ill. 208, 36 N.E.2d 245 (1941) (13 years); City of St. Louis v. International Harvester Co., 350 S.W.2d 782 (Mo. 1961) (11 years); A. Gettelman Brewing Co. v. City of Milwaukee, 245 Wis. 9, 13 N.W.2d 541 (1944) (11 years). See 4 Nrchols \$12.3151 (4th ed. 1962).

501 BONBRIGHT, op. cit. supra note 31 , at 410 .

s1 That property values surrounding public improvements do increase greatly, see Walther, Effect of Jet Airports on Market Value of Vicinage Real Estate, 27 APPRAISAL J. 465 (1959); Balfour, America's Highway Problems and Their Likely Effect on Real Estate Markets, 22 APPRAISAL J. 497 (1954); Ryan, A Method of Measuring Changes in the Value of Residential Properties, in LAND ACQUISIION-1959 at 79 (Highway Research Board Bull. No. 239, 1959). 
designated to be taken for the improvement is subject to "planning blight" and should cease its upward trend and probably start a downward plunge, contingent in part on the expectancy of a small or large offer by the condemnor or award by a court. The plight of the property owner in an area designated as blighted was recognized in City of Cleveland v. Kacmarik:

Beyond any doubt it is possible for much injustice to creep into the proceedings particularly when there is a wholesale taking of property in a given area. The very size of the problem of taking many parcels places a heavy burden on the condemnor, the property owners and the courts. Each separate parcel must be appraised, its owners called in to confer about settlement, and in the absence of agreement, its value must be determined by a jury. As houses begin to come down, tenants in nearby homes move out, the neighborhood deteriorates or is deserted, vandalism often sets in, appearances and values depreciate with the result that frequently the property owner is greatly handicapped in presenting his case to the jury by the time his land gets into court. 52

The valuation date thus becomes crucial. Choice of the earliest possible date would be most beneficial to both the public and the owner whose property is condemned. This would be the date when the porperty was first mentioned for probable public acquisition, or when it was designated as "blighted"- the date when the improvement became so probable that buyers and sellers would take it into account in their negotiations. This may be sometime during public hearings in urban renewal or highway mapping, the date the resolution is passed declaring the area "blighted," or the date of the resolution or law which actually authorizes the project if there has been little or no public discussion. ${ }^{53} \mathrm{In}$ terms of the three stages set out above, the proper date would be the second stage when the final decision is made and, in some instances, the first stage. The earlier valuation date should be beneficial to the public since most modern public improvements are of such large scope that they can seldom be accomplished at one fell swoop. This is particularly true in urban renewal, where buildings, mostly residential, are progressively taken and demolished; or where the project is expanded due to the availability of more funds or because borderline buildings have become "slums" since the start of the project. In the meantime, property values in the area will have risen because of the proximity to the improvement and the action of supply and

52177 N.E.2d 811, 813 (Ohio C. P. 1961). See statement by Mr. Herbert J. Hannoch, 1959 Report to the Committee on Condemnation and Condemnation Procedure, Municipal Law Section, ABA, p. 121 n.1 (mimeo), commenting on the case of Wilson v. City of Long Branch, 27 N.J. 360, 142 A.2d 837 (1958); Johnson, supra note 18; Randall, Appraisal of Damages Caused by Proximity to Jet Airports, 22 APPRAISAL, J. 39 (1954); Slonim, Injustices of Eminent Domain, 25 APPRAISAL J. 421 (1957).

53 Compare City of St. Louis v. International Harvester Co., 350 S.W. $2 d 782$ (Mo. 1961), where the issue was severance damages in a partial taking. The court held unconstitutional a provision in the City Charter which fixed the date of valuation as the date of the authorizing ordinance. 
demand: As residential units are demolished, the demand for those remaining will increase, and their price (market value) will rise. The public authority, in a subsequent taking, will thus have to deal with the higher values that its own activity has caused.

Yet the earliest accepted valuation date 54 is the date on which the condemnation petition is filed. As to the property to be taken, this, or a later date, is most favorable to the condemnor and least favorable to the condemnee. But it is uniformly held that the resolution to take, or the designation of an area as blighted, does not constitute a taking, which prevents the earlier date from being the date of valuation. 55 The remainder of this comment will deal with judicial analysis of the problem of determining the proper valuation date, and possible solutions.

\section{Decrease In Value: Just Compensation to The Individual}

The mere use of the word "taking" in this discussion is significant. It epitomizes a conflict that began long before urban redevelopment or limitedaccess highways were conceived: When does public action so exceed the state's police power as to be a taking and require resort to eminent domain and just compensation? Speaking for the Massachusetts Supreme Court in 1851, Chief Justice Shaw articulated the much-quoted description of police power:

We think it is a settled principle, growing out of the nature of well ordered civil society, that every holder of property, however absolute and unqualified may be his title, holds it under the implied liability that his use of it may be so regulated, that it shall not be injurious to the equal enjoyment of others having an equal right to the enjoyment of their property, nor injurious to the rights of the community. All property in this commonwealth . . . is derived directly or indirectly from the government, and held subject to those general regulations, which are necessary to the common good and general welfare....

This is very different from the right of eminent domain, the right of a government to take and appropriate private property to public use, whenever the public exigency requires it; which can be done only on condition of providing a reasonable compensation therefor. The power we allude to is rather the police power, the power vested in the legislature by the constitution, to make, ordain and establish all manner of wholesome and

54 See notes 38-43 supra and accompanying text.

55 See e.g., Danforth v. United States, 308 U.S. 271 (1939); United States v. Sponenbarger, 308 U.S. 256 (1939); Bauman v. Ross, 167 U.S. 548 (1897); 23 Tracts of Land v. United States, 177 F.2d 967 (6th Cir. 1949); United States v. Certain Lands, 47 F. Supp. 934 (S.D.N.Y. 1942); Zurn v. City of Chicago, 389 Ill. 114, 59 N.E.2d 18 (1945); City of St. Louis v. International Harvester Co., 350 S.W.2d 782 (Mo. 1961); Wilson v. City of Long Branch, 27 N.J. 360, 142 A.2d 837 (1958); State v. Vaughan, 319 S.W.2d 349 (Tex. Civ. App. 1958). Cf. Department of Pub. Works \& Bldgs. v. Wolf, 414 Ill. 386, 111 N.E.2d 322 (1953). The rule is different in Pennsylvania. See PA. STATs. ch. 36, \& 670-208 (1961); Petition of Lakewood Memorial Gardens, Inc., 381 Pa. 46, 112 A.2d 135 (1955). See infra notes 78-87 and accompanying text. 
reasonable laws, statutes and ordinances, either with penalties or without, not repugnant to the constitution, as they shall judge to be for the good and welfare of the commonwealth, and of the subjects of the same.56

A good, literary description, however, does not solve the definitional problem of the limits of the police power. Such a solution is at best difficult, perhaps impossible. 57 Too often, courts have ignored the problem and resorted to mere quotation and glittering generalities. Occasionally, words of warning appear. The most famous are those of Mr. Justice Holmes in Pennsylvania Coal Co. v. Mahon:

In general it is not plain that a man's misfortunes or necessities will justify his shifting the damages to his neighbor's shoulders. ... We are in danger of forgetting that a strong public desire to improve the public condition is not enough to warrant achieving the desire by a shorter cut than the constitutional way of paying for the change. As we already have said, this is a question of degree-and therefore cannot be disposed of by general propositions....

We assume, of course, that the statute was passed upon the conviction that an exigency existed that would warrant it, and we assume that an exigency exists that would warrant the exercise of eminent domain. But the question at bottom is upon whom the loss of the changes desired should fall. 58

Quite often the solution to the problem will depend on the time-honored game of balancing the public interest against individual rights. All Mr. Justice Holmes could offer was that "the general rule at least is, that while property may be regulated to a certain extent, if regulation goes too far it will be recognized as a taking." 59

At least one commentator has attempted a definitional analysis of the limits of non-compensable regulation which as yet has received no satisfactory rebuttal. 60 Professor Allison Dunham draws a distinction "between restricting (that is zoning) in order to prevent one land use from putting an external harm on others, and restricting or zoning to compel a land use which

56 Commonwealth v. Alger, 61 Mass. (7 Cush.) 53, 84-85 (1951).

57 Chief Justice Shaw recognized the problem in the sentence immediately following the textual quote: "It is much easier to perceive and realize the existence and sources of this power, than to mark its boundaries, or prescribe limits to its exercise." Id. at 85.

58260 U.S. 393, 416 (1922).

$59 \mathrm{Id}$. at 415 . Mr. Justice Brandeis, dissenting, thought the balance to be on the other side. Id. at 416-22. Compare Mahon with Consolidated Rock Prod. Co. v. City of Los Angeles, 57 Cal. 2d 515, 20 Cal. Rptr. 638, 370 P.2d 342 (1962).

60 Dunham, A Legal and Economic Basis for City Planning, 58 CoLum. L. Rev. 650 (1958). The analysis is dismissed rather abruptly in Krasnowiecki \& Paul, The Preservation of Open Space in Metropolitan Areas, 110 U. PA. L. REv. 179, 190 (1961), apparently only on the basis that Professor Dunham's theory does not offer a convenient vehicle for the policy which the authors advance. The reader is directed to Professor Dunham's article for more than the brief summary of his conclusions contained in this comment. 
will benefit others."61 In the former, non-compensable category fall those cases that prevent a property owner from imposing costs on neighbors who will reap no benefit from the activity (the classic nuisance case); that impose on the individual the costs of improvements necessitated by his activity, but only if the public as a whole will not benefit from the improvement other than incidentally (requirement of off-street parking for a new apartment development);62 and, on a theory of paternalism, that protect the individual from his own folly. 63 If, however, none of these factors appears, but rather the government purpose is to compel an individual to furnish a benefit to the public, then there is an unreasonable exercise of the police power 64 and the public must "take" the property and pay just compensation in order to obtain the desired benefit. Not unnaturally this "legalism" is based on underlying ethical and political considerations.

An owner is compelled to furnish a public benefit just as much when his land is taken for the runway of an airport as when he is prevented from building upon his land so that airplanes may approach the runway. In the former the landowner is paid without question; in the latter there is an attempt from time to time to compel the landowner to furnish the easement of flight without compensation by restricting building. The evil of the latter system is that there is no approximation of equal sharing of cost or of sharing according to capacity to pay as there is where a public benefit is obtained by subsidy or expenditure of public funds. The accident of ownership of a particular location determines the persons in the community bearing the cost of increasing the general welfare. A further consequence of an attempt to obtain a benefit by means of a restriction is that the full cost of the public benefit is thereby concealed from those in our democratic society who are given the power of deciding whether or not they want to obtain a benefit. 65

\section{A. The Official Map}

Judicial treatment of the "official map" 66 offers a good example of the police power-taking dichotomy. In Forster v. Scott, 67 the New York Court of

61 Dunham, supra note 60 , at 664 .

62 Compare Ayres v. City Council, 34 Cal. 2d 31, 207 P.2d 1 (1949), with Pioneer Trust \& Sav. Bank v. Village of Mount Prospect, 22 IIl. 2d 375, 176 N.E.2d 799 (1961), and Miller v. City of Beaver Falls, 368 Pa. 189, 82 A.2d 34 (1951).

${ }^{63}$ Cf. McCarthy v. City of Manhattan Beach, 41 Cal. 2d 879, 264 P.2d 932 (1953).

64 Cf. Vernon Park Realty, Inc. v. City of Mount Vernon, 307 N.Y. 493, 121 N.E.2d 517 (1954).

65 Dunham, supra note 60, at 665. See Whyte, Development Rights (1958) (mimeo; preliminary draft of an article, on file in the University of Chicago Law Library).

66 The standard work is Bassett \& Williams, Model Planning Laws (1935). See further, Haar, The Master Plan: An Impermanent Constitution, 20 LAw \& CoNIEMP. PROB. 353 (1955); Kucirek \& Beuscher, Wisconsin's Official Map Law, 1957 WIs. L. Rev. 176; Kratovil \& Harrison, Eminent Domain-Policy and Concept, 42 CaLr. L. Rev. 596, 629-52 (1954); Cram, Master Planning Creates Clouds on Titles, 35 Mrсн. ST. B. J. 9 (1950.

67136 N.Y. 577, 32 N.E. 976 (1893). 
Appeals was confronted with the question of the constitutionality of an official map on which a street had been plotted but not opened. The statute under which the map was authorized provided:

No compensation shall be allowed for any building, erection, or construction which at any time, subsequent to the filing of the maps, plans, or profiles ... may be built, erected, or placed in part or in whole upon or through any street, avenue, road, public square, or place exhibited upon such maps, plans, or profiles. 68

The presence of this provision led the court to hold the map unconstitutional. It effectively prevented the owner from building on his property without compensation, thus impairing both the value of the land and the owner's power of disposition.

The legislative answer to Forster was to amend the statute by deleting the objectionable building exclusion provision. The new law provided that "for the purpose of preserving the integrity of such official map or plan no permit shall hereafter be issued for any building in the bed of any street or highway" 69 shown on the map. However, there was a proviso which gave to the appropriate agency the power to issue a permit "if the land within such mapped street or highway is not yielding a fair return... to the owner...."70 The proviso was sufficient for the Court of Appeals to hold the new law constitutional in Headley $v$. City of Rochester.71 A substantially similar Wisconsin official map was held constitutional in State ex rel. Miller $v$. Manders. 72 The "saving clause" was there worded in a negative manner: "Such board [municipal board of appeals] shall refuse a permit where the applicant will not be substantially damaged by placing his building outside the mapped street, highway or parkway."73 To sustain the constitutionality of the map, the court read the provision as imposing the converse duty "to grant the permit if the applicant property owner would be substantially damaged, if the permit were to be denied."'74

In Headley, the complainant had not applied for a building permit; in

68 As quoted id. at 582,32 N.E. at $976-77$.

6920 N.Y. CONSOL. LAWs $\$ 35$ (1926).

70 Ibid.

71272 N.Y. 197, 5 N.E.2d 198 (1936). "A statutory requirement that a city must acquire title to the land in the bed of the streets shown on the general map or plan, and provide compensation for the land taken, would create practical difficulties which would drastically limit, if, indeed, they did not render illusory, any power conferred upon the city to adopt a general map or plan which will make provision for streets which will be needed only if present anticipations of the future development of the city are realized. On the other hand, to leave the land in private ownership, and, without compensation to the owner, incumber it with restrictions upon its use which would result in diminution in its value might be inequitable and perhaps even beyond the power of the State." Id. at 201-02, 5 N.E.2d at 200.

722 Wis. 2 d 365, 86 N.W.2d 469 (1957).

73 Wis. STATS. $\$ 62.23(6)(d)$ (1957).

742 Wis. $2 d$ at 372,86 N.W.2d at 473. 
Manders, a permit had been denied but no complaint of damage was made on appeal. Each case, therefore, was essentially a test case, since the only attack was on the constitutionality of the official map as an unreasonable exercise of the police power. When an application for a permit has been denied and damage alleged, the courts have been less willing to uphold a map as applied to a particular piece of property. On such facts the New York Supreme Court declared void the official map of New Rochelle. 75 The court phrased the issue thus: "May the defendant-City, without compensating the plaintiff, tie up, for an indefinite period of time, the use of all of the plaintiff's property by a threatened future taking for highway purposes?"76 The court's answer was "no." Professor Dunham's analysis would seem to hold good here. If all of an individual's property is so restricted as to allow no alternative use except vacant land, then the police power is exercised unreasonably. To obtain the desired benefit, the public must compensate the individual. 77

The Pennsylvania street cases are an aberration from this line of authority. In 1871 , the supreme court reached a result contrary to Forster $v$. Scott. It held constitutional a statute denying compensation for buildings or other improvements constructed in a street bed subsequent to the plotting of such street on a map or plan. ${ }^{78}$ There was continued recognition that the mere plotting of a street is not a "taking" to require compensation, since the taking does not occur until the street is later opened. But the property owner in the meantime was damaged, because at the time of taking he could not realize the value of any improvements constructed subsequent to the plotting. This effectively impaired the value of the property. The court fashioned a remedy in $R e$ South Twelfth Street,79 a street opening proceeding, where the city attorney argued that the reduced value at the time of opening was the correct measure of compensation. The court answered:

But who is responsible for this reduction? Not the owner; the impairment of value resulted from nothing he had done, but as the immediate consequence of the steps taken by the municipality towards the appropriation, in invitum, of the owner's land. ... This then is the contention, that the municipality in the furtherance of public ends, having stripped the land of

75 Roer Constr. Corp. v. City of New Rochelle, 136 N.Y.S.2d 414 (Sup. Ct. 1954).

$76 \mathrm{Id}$. at 417 (italics in the original).

77 See also State v. Griggs, 89 Ariz. 70, 358 P.2d 174 (1960); Town of Windsor v. Whitney, 95 Conn. 357, 111 Atl. 354 (1920); City of Miami v. Romer, 73 So. 2d 285 (Fla. 1954); Department of Pub. Works \& Bldgs. v. Wolf, 414 Ill. 386, 111 N.E.2d 322 (1953); Grosso v. Board of Adjustment, 137 N.J.L. 630, 61 A.2d 167 (1948); Mansfield \& Swett, Inc. v. Town of West Orange, 120 N.J.L. 145, 198 Atl. 225 (1938); State v. Carragan, 36 N.J.L. 52 (1872). $C f$. Kirschke v. City of Houston, 330 S.W. 2d 629 (Tex. Civ. App. 1959), which held that there is no action for damages for a refusal to issue a building permit; the proper remedy is to sue to compel issuance of a permit or to enjoin interference with building. Hammon v. Wichita County, 290 S.W. 2d 545 (Tex. Civ. App. 1956).

${ }^{78}$ In re Forbes Street, $70 \mathrm{~Pa} .125$ (1871).

79217 Pa. 362, 66 Atl. 568 (1907). 
nearly its entire value, now when it seeks to accomplish fully its purposes in connection therewith, is to be allowed to acquire the land by paying a sum measured by the little value the municipality has left in it. Such a result would be a travesty on the constitutional provision which requires in all such cases just compensation to be made for the property taken. 80

The remedy was not to assess separate damages both at the time of plotting and taking. Rather, at the time of taking the property would be valued in ignorance of the fact that it could not be compensably improved.81 This did not change the date of valuation; that remained at the date of taking, with the qualification that any damage caused by the previous plotting and consequent restriction would be compensated. Thus, the owner was not penalized if his property actually rose in value subsequent to the plotting. 82

Recently, however, the Pennsylvania court raised grave doubts as to the wisdom and constitutionality of the rule. In Miller v. City of Beaver Falls, 83 the defendant-city, by ordinance pursuant to a state enabling act, designated plaintiff's property in a general plan for public parks. The enabling act contained a provision similar to the one with which the street cases were concerned: An owner was to be denied the right to damages for any building placed on his property subsequent to the designation of that property for acquisition as a park. The act further provided that the ordinance would be void if such property was not acquired within three years of designation. 84 The court held that the statute was a taking of plaintiff's property without just compensation, and thus unconstitutional. It referred to the "questionable constitutionality" of the street cases and said their extension "would violate either the letter or the spirit of the Constitution." 85

The injustice to property owners of permitting a municipal body to tie up an owner's property for three years must be apparent to everyone. The city can change its mind and abandon or refuse to take the property at the end of three years; but in the meantime the owner has been, to all intents and purposes, deprived of his property and its use and the land is practically unsalable. He cannot build thereon because if he does the law is clear

$80 \mathrm{Id}$. at 366, 66 Atl. at 569.

81 Ibid.; Herman v. North Pa. R.R., 270 Pa. 551, 113 Atl. 828 (1921). Cf. Re Appointment of Viewers, $103 \mathrm{~Pa}$. Super. 212, 158 Atl. 296 (1931).

82 In Griffin v. City of New Castle, $88 \mathrm{~Pa}$. Super. 439 (1926), the city argued that the date of valuation should be in 1901, when the street was plotted. Apparently there had been an increase in land values since that time; otherwise the city would have had nothing to gain from an earlier valuation date. The court disagreed with the city, setting the value date in 1921 , when the street was opened.

83368 Pa. 189, 82 A.2d 34 (1951).

84 Compare the statute held constitutional in Philadelphia Parkway Opening, $295 \mathrm{~Pa}$. 538,145 Atl. 600 (1929). The statute gave the property owner the right to compensation if after five years from the plotting of a street it had not been opened.

$85368 \mathrm{~Pa}$. at $196,82 \mathrm{~A} .2 \mathrm{~d}$ at $37-38$. 
that he cannot recover damages for the loss of any building erected within the plotted lines....86

Unfortunately, the court did not discuss the South Twelfth Street case or the wisdom of the remedy there formulated, implicitly rejecting it as not correcting the unconstitutionality of the rule now restricted only to street cases. 87

Analogous to the official-map cases is the attempt by the use of zoning to hold down property values in anticipation of future condemnation. A zoning ordinance, like an official map, is an exercise of the police power and will be struck down as an unconstitutional taking of property without just compensa-

86 Id. at 193-94, 82 A.2d at 36.

87 The court's language was so strong as to raise the possibility that even the street cases would be overruled. If that were done, then the Pennsylvania rule would be in apparent accord with New York and Wisconsin. In Petition of Lakewood Memorial Gardens, Inc., 381 Pa. 46, 112 A.2d 135 (1955), despite a strong dissent echoing the Miller language, the court did not question the constitutionality of another state statute which fixed the date of taking property for highway purposes as the date the right of way is approved by the Secretary of Highways and the Governor and filed as a public record. The court held that when a physical entry occurred, which it said was the constitutional date of taking, the taking would relate back to the "constructive" taking provided by the statute. As the dissent indicated, however, the owner lost the use of his property during the interregnum and for full compensation via Miller he should receive the value of that loss. See also Rosenblatt $v$. Turnpike Comm'n, 398 Pa. 111, 157 A.2d 182 (1959).

The court in Miller attempted an unsatisfactory distinction between parks and streets, the former being less "necessary" than the latter, which was picked up as an explanation of the case in Cutler, Legal and Illegal Methods for Controlling Community Growth on the Urban Fringe, 1961 Wis. L. Rev. 370, 389. However, just one year prior to Miller, in In re Certain Land, $364 \mathrm{~Pa}$. 71, 70 A.2d 847 (1950), a case involving acquisition of land for playgrounds under a different but similar statute to the one in Miller, the court held that the date of taking was the date the ordinance was passed which designated the property for acquisition. It did not hold the statute unconstitutional. The result of the holding was that the city could not abandon condemnation of the subject parcel without the consent of the owner. Unless we are to distinguish parks and playgrounds and say that the latter are more closely related to streets than the former, the dubious scale of "necessity" does not explain the Miller holding.

The correct distinction appears to depend on whether the original "plotting" ordinance will be deemed a taking. Prior street cases found this to be true. See In re Samson Street, 293 Pa. 483, 143 Atl. 134 (1928); In re Philadelphia Parkway, 250 Pa. 257, 95 Atl. 429 (1915); Chelten Trust Co. v. Blankenburg, 241 Pa. 394, 88 Atl. 664 (1913); Shields v. City of Pittsburgh, $201 \mathrm{~Pa}$. 328, 50 Atl. 820 (1902). If this is the correct interpretation, then even a subsequent street case under an enabling act similar to the one in Miller will reach the Miller result.

Under this interpretation Professor Dunham's analysis would also explain the Pennsylvania cases. It is an unreasonable exercise of the police power to compel an individual to confer a public benefit without compensation, and this is done when the restriction effectively prevents any other use (Miller, Samson Street, Chelten Trust Co.). If such is the case under an enabling act which allows the court to do so, the date the designating ordinance is passed will be the date of taking and valuation, and the attempt to restrict the use of the property need not be held an unconstitutional exercise of the police power (Lakewood, Samson). If, however, the ordinance is not conclusive as a taking it will be unconstitutional (Miller). Finally, if another reasonable use for the property exists, then either the original street cases will be held good law, even as to parks, or the New York-Wisconsin approach will be adopted. If it were not for the Lakewood and In re Certain Land, cases, the latter official map approach would be the most reasonable reading of Miller. 
tion if it is unreasonably exercised. Again, it must be asked whether the purpose of the ordinance is to restrain one property owner from imposing external costs on his neighbors, or whether the purpose is to compel the individual to furnish a benefit to the public without just compensation. The cases unanimously hold that a zoning ordinance whose sole purpose is to keep property values at a reduced level in order to have a smaller condemnation award in the future is unconstitutional.88 Although the courts use strong language, there probably is a necessary qualification, since the essential purpose of the official map is the same. Zoning laws have a built-in "savings clause": Property owners may apply for variances or exceptions and if either is unreasonably withheld, a court may compel issuance. Again, the test would seem to be not whether values are in fact reduced, 89 but whether the owner is precluded from all reasonable use of his property.

The [condemning authority] ... is not to be left without commendation for its justifiable effort to acquire the subject property for public use at the least possible expense to the public treasury. This is their logical and proper function. However, we cannot disregard the fact that they are here exercising one of the three highest powers of sovereignty. We have not yet reached the point where the rights of an individual in the enjoyment of his private property are to be subordinated to the demands of government except upon payment of just compensation in an orderly proceeding conducted in a fashion consistent with the requirements of due process of law.90

88 Symonds v. Bucklin, 197 F. Supp. 682 (D. Md. 1961); Robertson v. City of Salem, 191 F. Supp. 604 (D. Ore. 1961); Kissinger v. City of Los Angeles, 161 Cal. App. 2d 454, 327 P.2d 10 (1958); Board of Comm'rs v. Tallahassee Bank \& Trust Co., 108 So. 2 d 74 (Fla. App. 1959); City of Miami v. Romer, 73 So. 2d 285 (Fla. 1954); Congressional School of Aeronautics, Inc. v. State Roads Comm'n, 218 Md. 236, 146 A.2d 558 (1958); Robyns v. City of Dearborn, 341 Mich. 495, 67 N.W.2d 718 (1954); Henle v. City of Euclid, 97 Ohio App. 248, 125 N.E.2d 335 (1954); State ex rel. Tingley v. Gurda, 209 Wis. 63, 243 N.W. 317 (1932).

89 "Historically, the first crucial issue in zoning law was whether the owner of vacant land well adapted for high-value industrial and commercial uses could be made to bear the loss when such uses, obviously not noxious in themselves, were forbidden in neighborhoods zoned for private residences. The validity of such zoning was sustained and the resulting sharp drop in value of the vacant land was held non-compensable." Kratovil \& Harrison, supra note 66, at 628. See Village of Euclid v. Ambler Realty Co., 272 U.S. 365 (1926). Cf. City of Miami v. Romer, supra note 88.

In Congressional School of Aeronautics, Inc. v. State Roads Comm'n, supra note 88, Chief Judge Brune discussed the relationship of the question of zoning for future condemnation to the official map cases. His discussion indicates that the court would follow the reasoning of the map cases in deciding the question of the reasonableness of a zoning ordinance. He refused to decide the latter in vacuo.

90 Board of Comm'rs v. Tallahassee Bank \& Trust Co., 108 So. 2d 74, 87 (Fla. App. 1959). Although the courts are agreed on this as a matter of law, there is disagreement on the procedure for attacking the alleged abuse of police power. The majority position seems to be that the zoning ordinance may not be collaterally attacked in an eminent domain proceeding. Congressional School of Aeronautics, Inc. v. State Roads Comm'n, 218 Md. 236, 146 A.2d 558 (1958), and cases cited therein. However, some jurisdictions apply the "Texas Rule": If the trial judge is of the opinion that the zoning is unreasonably restrictive 


\section{B. Planning Blight}

In Wilson $v$. City of Long Branch,91 a group of property owners sued to set aside a finding by the local planning board that the area in which their property was located was "blighted." They contended, inter alia, that the finding in itself constituted a taking, since the value of their property was thereby diminished or destroyed. The court held that the diminution, if there was any, was "akin to the result which flows from municipal zoning," that the finding of blight was "inspired by the valid exercise of police power" and was dammum absque injuria.92 On the basis of cases that hold that a statute or recordation of a map is not a taking, 93 the court denied the validity of the plaintiffs' argument.

he may submit the question of reasonableness to the jury, along with evidence of a "reasonable probability" of a zoning change in the "foreseeable future" and evidence of value for the less restricted uses that will probably be allowed. There appears to be good reason for adopting this less restrictive, though more cumbersome, approach. "It appears to us that it would be totally unjustifiable to hold that the condemning authority could rely on the restrictive provisions of a zoning ordinance to depress land values and in the same litigation deny to the property owner an opportunity to defend himself and his property against the asserted ordinance on the ground of its alleged invalidity." Board of Comm'rs v. Tallahassee Bank \& Trust Co., supra at 81 , and cases cited therein. See also Pawson v. Sudbury, Ont. Ct. of App., [1954] I D.L.R. 10; Re Gibson and City of Toronto, App. Div., Ont. Sup Ct., 38 Ont. L.R. 20, [1913] XI D.L.R. 529.

9127 N.J. 360, 142 A.2d 837 (1958).

92 Id. at $374,142 \mathrm{~A} .2 \mathrm{~d}$ at 845 .

93 See notes 71-74 supra. The addition of "or damaged" to the "taking" clause in state constitutions has made no difference in the courts' holdings in this situation. See, e.g., ILL. CONST. art. II, $\$ 13$ (taken or damaged); N.J. CONST. art. I, $\S 20$ (taken); Wis. CoNST. art I, $\S 13$ (taken). The landmark case under an "or damaged" constitution is Rigney v. City of Chicago, 102 IIl. 64 (1882). The court there held that loss of access to property is compensable under the "or damaged" provision. "Taking" referred only to direct physical damage to property; "or damaged" extended to cover physical disturbance of a right of property. "In all cases, to warrant a recovery, it must appear there has been some direct physical disturbance of a right, either public or private, which the plaintiff enjoys in connection with his property, and which gives to it an additional value, and that by reason of such disturbance he has sustained a special damage with resepect to his property in excess of that sustained by the public generally." Id. at $80-81$. There has been general agreement with the requirement that there must still be some physical disturbance. See, e.g., People ex rel. Dept. of Pub. Works v. Symons, 54 Cal. 2d 855, 9 Cal. Rptr. 363, 357 P.2d 451 (1960) (no severance damages for decreased property value due to change from quiet residential area, loss of view, noise, fumes and dust from the new freeway); Kane v. City of Chicago, 392 III. 172, 64 N.E.2d 506 (1946).

The difficulty encountered when a declaration of blight severely limits the use of property is in the word "right" of property. Compare People v. Ricciardi, 23 Cal. 2d 390, 144 P.2d 799 (1943), and People ex rel. Tyson v. Kelly, 379 Ill. 297, 40 N.E.2d 510 (1942), with Weir v. Palm Beach County, 85 So. 2d 865 (Fla. 1956) and Nick v. State Highway Comm'n, 13 Wis. 2d 511, 109 N.W.2d 71 (1961). Thus far, the courts have been unwilling to hold that there is a compensable "right" in a situation of planning blight. But see Benson v. Housing Authority, 145 Conn. 196, 140 A.2d 320 (1958), where the court held that an area resident had no cause to complain of decreased value of his property allegedly caused by the proposed erection of moderate rental housing in the neighborhood. The court noted that the result might be different in an "or damaged" state. Indeed, in the words of the Rigney case, the property owner "has sustained a special damage with respect to his property in 
There is, however, one line of authority in eminent domain cases that would support recovery of more than the diminished value in a subsequent condemnation proceeding. If the condemnor caused a physical injury to the subject property that impaired the market value, the condemnation award will not be diminished merely because the date of valuation was subsequent to the diminution. 94 Nor may the condemnor argue for a lower award because the property was peculiarly susceptible to condemnation.95 In Congressional School of Aeronautics, Inc. v. State Roads Comm'n, 96 Chief Judge Brune ruled that it was reversible error to allow a witness for the condemnor to testify to the value of the subject property as diminished by the prospective condemnation and the limited time a willing purchaser would be able to use the property.

This court has held that evidence of value based upon the effect of the taking involved in a pending condemnation suit is inadmissible. ... We think that the rule is as applicable to considerations which might tend to depress values as to those which might tend to increase them and that it should also extend to the effect of the prospect of the taking. If the prospect of taking is to be used in gauging market value at the time of the taking, we should get into something of a vicious circle. 97

The leading case in this area is United States $v$. Miller. 98 In 1932, California authorized the Central Valley Reclamation Project. President Roosevelt in 1935 approved construction of the entire project as a federal improvement. Congress appropriated funds for it in 1936 and 1937, and on August 26, 1937, again authorized the project. Relocation of part of the right-of-way of the Central Pacific Railroad was necessary due to flooding caused by the project. As. of 1937, three alternative routes for the relocation were being discussed. On December 14, 1938, the United States filed a condemnation complaint and declaration of taking to provide for the relocation. Respondents-property owners argued that the date of valuation was when the declaration of taking was filed. The government basically agreed with this, but objected, arguing

\footnotetext{
excess of that sustained by the public generally." Logically, he should be entitled to recover compensation for this loss; otherwise, he is forced to furnish a benefit to the public, by way of decreased condemnation costs, without receiving just compensation. $C f$. Dunham, supra note 60 .

94 Olson v. United States, 292 U.S. 246(1934); $c f$. Department of Pub. Works \& Bldgs. v. Wolf, 414 IIl. 386,111 N.E.2d 322 (1953). It was held error to exclude evidence that a neighboring property owner had sold his land for $\$ 200-\$ 250$ below its otherwise market value because "he had learned that the sewage disposal plant was to be constructed in the immediate neighborhood." Greenman v. City of Fort Worth, 308 S.W.2d 553, 557 (Tex. Civ. App. 1958).

95 City of Chicago v. Lederer, 274 III. 584,113 N.E. 883 (1910.

96218 Md. 236, 146 A.2d 558 (1958).

97 Id. at $249-50,146$ A.2d at 565 .

98317 U.S. 369 (1943).
} 
that respondents were not entitled to "any increment of value due to the Government's authorization of, and commitment to, the project," as of August 26, 1937.99 The trial court agreed with the government's contention, but it was reversed by the Ninth Circuit Court of Appeals. ${ }^{100}$ On certiorari, the Supreme Court unanimously reversed the court of appeals and affirmed the judgment of the trial court.

The issue, according to Mr. Justice Roberts, was: "Should the owner have the benefit of any increment of value added to the property taken by the action of the public authority in previously condemning adjacent lands? If so, were the lands in question so situate as to entitle respondents to the benefit of this increment?'101 The opinion then traced the history of the market value standard and agreed that value was to be determined as of the date of taking, with the qualification, however, that any increment due to the initiation of the project should be disregarded in certain cases. To determine exclusion or inclusion, the Court phrased the test:

The question then is whether the respondents' lands were probably within the scope of the project from the time the Government was committed to it. If they were not, but were merely adjacent lands, the subsequent enlargement of the project to include them ought not to deprive the respondents of the value added in the meantime by the proximity of the improvement. If, on the other hand, they were, the Government ought not to pay any increase in value arising from the known fact that the lands probably would be condemned. The owners ought not to gain by speculating on probable increase in value due to the Government's activities. ${ }^{102}$

Although the facts of the case and the Court's language dealt only with the question of enhancement of value from the government project, the case is read as applicable also to diminution in value. "The court must exclude any depreciation in value caused by the prospective taking once the Government 'was committed' to the project."'103

99 Id. at 372.

100125 F.2d 75 (9th Cir. 1942).

101317 U.S. at 375. There is, however, no indication in either the Supreme Court or court of appeals opinions that there had in fact been prior condemnation of adjacent lands.

102 Id. at 377. "If a distinct tract is condemned, in whole or in part, other lands in the neighborhood may increase in market value due to the proximity of the public improvement erected on the land taken. Should the Government, at a later date, determine to take these other lands, it must pay their market value as enhanced by this factor of proximity. If, however, the public project from the beginning included the taking of certain tracts but only one of them is taken in the first instance, the owner of the other tracts should not be allowed an increased value for his lands which are ultimately to be taken any more than the owner of the tract first condemned is entitled to be allowed an increased market value because adjacent lands not immediately taken increased in value due to the projected improvement." Id. at 376-77.

103 United States v. Virginia Elec. \& Power Co., 365 U.S. 624, 636 (1961); see also Murray v. United States, 130 F.2d 442 (D.C. Cir. 1952); United States v. 85, 237 Acres of Land, 157 F. Supp. 150 (S.D. Tex. 1957); A. Gettelman Brewing Co. v. City of Milwaukee, 245 Wis. 9, 13 N.W.2d 541 (1944). 
The case law concerning recovery for diminution is not clear, due mainly to the lack of cases dealing with the problem. What has been made clear, however, is that the pivotal concept in the Miller rule is causation: What diminution was "due to" the proposed improvement? Unfortunately for the property owner, the courts that purportedly adhere to the rule view compensable damage conservatively. The Wisconsin Supreme Court has gone so far as to hold that Miller was not concerned with delay between the time of the decision to take and the eminent domain proceeding.104 Recovery in Wisconsin for diminished value seems to be limited to a diminution akin to that which would occur if a sewage disposal plant were constructed on neighboring property. With due deference, however, it is submitted that the delay necessarily incident to the exercise of eminent domain was exactly what Miller dealt with. Otherwise, there would be no difficulty with an increase or decrease between the proposal to take and the actual condemnation proceedings. The Wisconsin court's reading of the case is unwarrantedly narrow. The Missouri court has held that a decrease in rental value and inability to sell the property during the pendency of condemnation proceedings are only "personal" damages and not recoverable in an eminent domain proceeding. 105 These factors, however, directly relate to the market value of property, and thus are unlike other "incidental" non-compensable damages, such as loss of good will or moving expenses.

Illinois is one of the few states that does not accept the Miller rule as to enhancement or diminution, but the result in Chicago Housing Authority v. Lamar106 is the same as that in Missouri and Wisconsin. The defendantproperty owner alleged that after plaintiff and defendant began negotiations for voluntary purchase of the property defendant vacated the buildings, the property was subsequently vandalized, and the area in general deteriorated due to the piecemeal acquisition and demolition pursued by the redevelopment authority. Defendant asked either that plaintiff pay all damages "naturally and proximately resulting" from these conditions, or that the date of valuation be the date plaintiff made an offer to purchase the subject property rather than the date when the comdemnation petition was filed, which was more than a year later. Both pleas were rejected. As to the prayer for damages, the court found that the alleged injuries were " "necessarily incident to the ownership of property within a municipality possessing the power of

104 A. Gettelman Brewing Co. v. City of Milwaukee, supra note 103; see Wis. STAT. $\S 32.10$ (1957): "Where a depreciation in value results from an exercise of the police power, even though in conjunction with the taking by eminent domain, no compensation shall be paid for such depreciation."

${ }_{105}$ State ex rel. City of St. Louis v. Beck, 333 Mo. 1118, 63 S.W.2d 814 (1933). Compare Greenman v. City of Fort Worth, 308 S.W.2d 553 (Tex. Civ. App. 1958).

10621 III. 2d 362, 172 N.E.2d 790 (1961); see also Dong v. State ex rel. Willey, 90 Ariz. 148,367 P.2d 202 (1961), which reached the same result as Lamar, but with no indication of acceptance or rejection of Miller. 
eminent domain." "107 As to the second point, the court merely held that there were no Illinois cases "which authorize fixing a date of taking at a time prior to the filing of the petition for condemnation."108

Several of the cases suggest that the property owner may have an action in tort against the condemning authority for the damages that they cannot recover in a condemnation proceeding. 109 However, the problem of "causation" would only be magnified in a tort action. Moreover, even if the governmental body can be sued in tort, there are further complications. In Goddard $v$. District of Columbia Redevelopment Land Agency, ${ }^{110}$ plaintiffs sued under the Federal Tort Claims Act. It was alleged, inter alia, that the defendantcondemnor had unduly delayed proceedings to condemn plaintiffs' property, that the delay resulted in the increase of those blighting factors that were to be eliminated by the redevelopment project, and that the proceedings were delayed with a view to obtaining the property at a lower price. The District of Columbia Court of Appeals affirmed the trial court's dismissal of the suits on the ground that the time of taking was discretionary with the government employees involved, and that under the act the United States had not consented to suit for discretionary actions of its employees. The court did say that plaintiff was entitled to just compensation, but that his remedy was in the condemnation proceedings; other courts have not followed this dictum.

Only one case has been found where a property owner was held entitled to compensation in a similar situation. The facts, however, were harsher. In City of Cleveland v. Kacmarik,111 the condemnation suit was filed in May 1961. At that time there were two buildings on the subject property, although they had been vacated and vandalized due to the demolition by the city of other buildings in the redevelopment area and the resultant deleterious effect on remaining structures. In July 1961, because of the hazardous condition of the two buildings, they were razed by the city. The case went to trial in October 1961. In Ohio, the date of taking and valuation is the time of trial, and the

107 Id. at 367,172 N.E.2d at 793.

$108 \mathrm{Id}$. at 368-69, 172 N.E.2d at 794. See also Eckhoff v. Forest Preserve Dist., 377 IIl. 208,36 N.E.2d 245 (1941), where essentially the same problem as faced in Lamar was before the court, although the delay involved there was thirteen years; the court reached the same result. Compare Sanitary Dist. v. Chapin, 226 III. 499, 80 N.E. 1017 (1907) (delay after proceedings were begun). It is sometimes said that "the use of land until the taking is effected 'is deemed by the law to be sufficient compensation to the owner for the delay in assessing damages." "Connor v. Metropolitan Dist. Water Supply Comm'n, 314 Mass. 33, 41, 49 N.E.2d 593, 597 (1943); see also Benedict v. City of New York, 98 Fed. 789 (2d Cir. 1899); cf. Brown v. United States, 263 U.S. 78 (1923); Comment, Emminent Domain: Interest on the Award and Just Compensation, 28 U. CHI. L. REV. 339 (1961).

109 E.g., State ex rel. City of St. Louis v. Beck, 333 Mo. 1118, 63 S.W.2d 814 (1933); Upper Third St. Dev. Corp. v. City of Milwaukee, 8 Wis. 2d 595, 99 N.W.2d 687 (1959); A. Gettelman Brewing Co. v. City of Milwaukee, 245 Wis. 9, 13 N.W.2d 541 (1944).

110287 F.2d 343 (D.C. Cir. 1961).

11117 Ohio Op. 2d 135, 177 N.E.2d 811 (Ohio Ct. C.P. 1961). 
city alleged that it thus should not have to pay for the buildings, since they were not standing at that time. The court conceded that the demolition was for valid reason and that it was a valid exercise of the police power. The court held, however, that the city could not begin condemnation and then by a valid exercise of the police power escape payment for structures thereby destroyed.

The Court cannot get away from the observation that in this instance the City was exercising two powerful rights, given by law, which, used concurrently, have the effect of abridging the natural rights of the individual citizen, namely, the City's right of eminent domain and the right to use the strong arm of the police power.112

It is submitted that the result in Kacmarik would have been different if the city's own actions, i.e., redevelopment, had not accelerated the blight. If the buildings had been allowed to deteriorate to the point of being a public hazard so as to justify their demolition, not by preliminary causal acts of the city but by the owner's failure to act, the city should not have been required to compensate for their loss.113 The court's discussion of the pitfalls for property owners in large-scale urban redevelopment justifies this conclusion.114

If this analysis is correct, then it points to the reason why other cases have not reached a similar result. The causal connection between an original designation of blight or decision to acquire and demolish property, the subsequent deterioration of the general area because of this decision, and the consequent diminution of property values is not as clear as the causal relation between an attempted use of the police power as in a use of the official map or zoning to hold down property values for the future use of eminent domain. Indeed, it is not obvious that a designation of an area for redevelopment or for a new airport is an exercise of the police power, since such a designation is merely the primary essential step in the total project. Eminent domain is the ultimate means to be used to accomplish the objective. But the consequence of a designation of blight may be exactly the same as that of an official map. Commentators are agreed that a designation of blight may cast a cloud upon the property that effectively causes uninhabitability, destroys rental value, prevents resale and removes any justification for improvements. True, the government does not explicitly require this result by any restrictions placed on the

112 Id. at 814. But see Atchison, T. \& S.F. Ry. v. Southern Pac. Co., 13 Cal. App. 2d $505,517,57$ P.2d 575, 581 (1936) ("The market value is an effect and we are not governed by the cause that brings it about in order to determine it. The market value could have been neither greater nor less if the cause had been examined into." The court said that it was too difficult and only speculative to look into the cause of an alleged diminution.); A. Gettelman Brewing Co. v. City of Milwaukee, 245 Wis. 9, 13 N.W.2d 54I (1944) (court would not consider the cause of market value, which was allegedly diminished by the upgrading of a street); WIS. STAT. $\$ 32.10$ (1957) (quoted supra note 104).

${ }^{113}$ Cf. Kaperonis v. State Highway Comm'n, 251 Ia. 39, 99 N.W.2d 284 (1959); Hance

v. State Roads Comm'n, 221 Md. 164, 156 A.2d 644 (1959).

114 See a further quote from the Kacmarik case, supra note 52. 
property owners, but the original government action undeniably promoted the forces that led to the same result. Lack of intent by the condemnor to cause such a result is not an excuse; it is sufficient that the result was the "natural and probable consequence of the acts" of the government.115 It is submitted that the case analysis previously advanced not only justifies the Kacmarik result, but requires it.

The Supreme Court in United States v. Miller seemed to recognize a constitutional requirement that planning blight not go uncompensated. A recent federal district court opinion disagrees with this conclusion.116 $\mathrm{Mr}$.

115 Richard v. United States, 282 F.2d 901, 904 (Ct. Cl. 1960). But see A. Gettelman Brewing Co. v. City of Milwaukee, 245 Wis. 9, 13 N.W.2d 541 (1944). A court's hesitation to delve into the causes of value changes and strict adherence to the date of taking also can have unforeseen consequences to the condemnor when changes in the property take place after the date of valuation. It is usually held that the condemnee is not entitled to any increase in value after that date. Washington v. United States, 214 F.2d 33 (9th Cir. 1954); City of Chicago v. Farwell, 286 Ill. 415, 121 N.E. 795 (1919). But see Illinois Cities Water Co. v. City of Mount Vernon, 11 IIl. 2d 547, 144 N.E.2d 729 (1957) (public utility entitled to compensation for improvements made after date of valuation, the improvements being required by the Illinois Commerce Commission); Sanitary Dist. v. Chapin, 226 Ill. 499, 80 N.E. 1017 (1907) (unreasonable delay in the prosecution of condemnation proceedings). Nor can the condemnor benefit from any decrease in value. Edlin v. Security Ins. Co., 269 F.2d 159 (7th Cir. 1959). But see Schreiber v. Chicago \& E.R.R., 115 IIl. 340,3 N.E. 427 (1885) (lessee not entitled to compensation when lease expired between value date and date of award). Compare In re Certain Lands, 344 S.W.2d 104 (Mo. 1961). Absent bad faith, the condemnor can abandon the proceedings at any time prior to entry of judgment without liability for any loss to the property owner. Town of Trumbull v. Ehrsam, 148 Conn. 47, 166 A.2d 844 (1961); Hamer v. State Highway Comm'n, 304 S.W.2d 869 (Mo. 1957); Upper Third St. Dev. Corp. v. City of Milwaukee, 8 Wis. 2d 595, 99 N.W. 2d 687 (1959); 6 Nrchols $\$ 26.45$ (3d ed. 1953).

Three cases in which fire either damaged or destroyed buildings on the property being condemned between the date of valuation and the date when the award was made present the problem in an interesting perspective. In Edlin v. Security Ins. Co., supra, the court, purporting to follow Illinois law, held that even though the property owner had already received compensation for the property in condemnation proceedings, he was entitled to the insurance and the intervenor-condemnor could recover nothing. Conversely, in Redevelopment Agency v. Maxwell, 193 Cal. App. 2d 414, 14 Cal. Rptr. 170 (1961), the court held that risk of loss, "whether by fire or by vandalism," (id. at 419,14 Cal. Rptr. at 174) remains on the condemnee, regardless of insurance coverage. See also CAL. Crv. Proc. Code $\$ 1249.1$ (1961). Alabama, however, in Jefferson County v. Adwell, 267 Ala. 544, 103 So. 2d 143 (1958), made insurance the pivotal factor (a result deemed illogical by the California court): If the condemnee was covered by insurance, then the condemnor was entitled to a reduction of the condemnation award; if there were no insurance coverage, the risk would be on the condemnor. Since neither party is responsible for the damage, the Alabama rule seems the most equitable to both parties and should be adopted. Neither of the other positions is so "Iogical" and equitable as to command more respect.

116 In Foster v. Herley, 207 F. Supp. 71 (E.D. Mich. 1962), condemnation proceedings were instituted by the city of Detroit in 1949 . Only a portion of the included property was acquired before the proceedings were abandoned. However, a lis pendens continued in effect as to all of the property in the area until 1960; also, the owners heeded the advice of the city to do nothing to improve or maintain their property before it was acquired by the city. As a result the area decayed and the city ordered the houses razed. New condemnation proceedings were instituted for property designated but not acquired in 1949, "in which the property will be valued as unimproved property and the plaintiff will be denied any award 
Justice Stewart speaking for the Court in 1961, however, also recognizes the requirement:

[N]o weight should be given to the prospect of governmental appropriation. The value of the easement must be neither enhanced nor diminished by the special need which the Government had for it.... The court must exclude any depreciation in value caused by the prospective taking once the Government "was committed" to the project.... As one writer has pointed out, "[i]t would be manifestly unjust to permit a public authority to depreciate property values by a threat... [ [of the construction of a government project] and then to take advantage of this depression in the price which it must pay for the property" when eventually condemned.117

If the designation of property for acquisition causes the value to decrease, then the public should not benefit from its own action. Presumably an individual owner did nothing to cause a slum to develop; slum conditions result from a combination of forces. Nor is an owner responsible if his property is chosen as the location for a jet airport or a limited-access highway. The whole body politic should pay for an improvement that benefits the whole. When the sole benefit that he will receive is as a member of the public, the property owner should pay for the improvement to the same extent as other citizens; he should not be forced to "contribute" a part of the value of his property.

It is interesting to compare the situation in England, where there is no requirement of just compensation. The English, however, have had an extensive statutory experience culminating in the Town and Country Planning Act of 1959,118 which recognizes the existence of "planning blight."119 Property may be designated in a development plan for compulsory acquisition at a future time. Between designation and acquisition, the owner may be unable to sell his property except at a much reduced price. The act provides for a system of reverse condemnation which allows the owner to compel the planning authority to acquire his land immediately. ${ }^{120} \mathrm{It}$ has been pointed out that this

for the losses suffered over the past twelve years as a result of misfeasance and nonfeasance attributable to the City of Detroit." Id. at 72. Nevertheless, Judge Kaess held that there was no federal jurisdiction of plaintiff's claim for compensation for the decline in value. "[T] most that can be said is that a constitutional question lurks in the background." Id. at 73. "The action taken by the City of Detroit did not result in compensation being made or secured. Hence, it did not accomplish a taking of the plaintiff's property. . . . Whether damages should be awarded . . . is a matter to be determined under the law of torts." Id. at 72. (Emphasis added.) See also, Harrison-Halstead Community Group, Inc. v. Housing \& Home Fin. Agency, 310 F.2d 99 (7th Cir. 1962). Cf. Alfonso v. Hillsborough County Aviation Authority, 308 F.2d 724 (5th Cir. 1962).

117 United States v. Virginia Elec. \& Power Co., 365 U.S. 624, 635-36 (1961).

1187 \& 8 Eliz. 2, c. 53.

119 Town and Country Planning Act 1959, 7 \& 8 Eliz. 2, c. 53, part IV.

120 Compare WIS. STAT. $\$ 32.10$ (1961), providing for reverse condemnation where a body possessing the power of eminent domain has entered into possession of the property 
provision is not a complete answer to the problem.121 It does not, for example, provide for the man whose property is "blighted" by a plan but not designated for acquisition. The act, however, provides a commendable start.

\section{Avigation Easements}

Finally, a problem area in which the courts have thus far held the solutions unique to the area must be considered. Because of the recent Supreme Court decision in Griggs v. Allegheny County, 122 the problems relating to acquisition of avigation easements are of signal importance. 123 In United States v. Causby, 124 the Court, in an opinion written by Mr. Justice Douglas, affirmatively answered the initial question of whether there can be a taking by low-flying aircraft. In Griggs, again speaking through Mr. Justice Douglas the Court answered the question of who is the taker. Causby held that a property owner has rights in the superadjacent air space that can be infringed to such an extent as to constitute a taking for which he must receive compensation. It is not necessary that the property be rendered uninbabit in the classic "taking" situation; it is sufficient if there is "an intrusion so immediate and direct as to subtract from the owner's full enjoyment of the property and to limit his exploitation of it."'125 Thus, there is always a factual question of whether the property owner is so affected.126

In Griggs, a group of property owners, whose land was located under the approach and take-off lanes of the Greater Pittsburgh Airport, petitioned for a viewers' proceeding, alleging that their property was taken by interference from jets landing and taking off from the airport. Four opinions 127 in the case agreed that there was a taking under Causby. Their disagreement went to the identity of the taker. The defendant-county owned and operated the airport. A federal subsidy aided the facility's construction, in return for an agreement by the defendant to maintain a "master plan" for the airport, including the

but has not instituted condemnation proceedings. See Note, Reverse Eminent Domain: A New Look and Redefinition, 47 KY. L.J. 215 (1959).

121 Heap, Planning Blight, 1961 J. PlaN. \& PROP. L. 507.

122369 U.S. 84 (1962); see Dunham, Griggs v. Allegheny County in Perspective: Thirty Years of Supreme Court Expropriation Law, 1962 SUP. CT. REv. 63, 65.

${ }^{123}$ See generally Harvey, Landowners' Rights in the Air Age: The Airport Dilemma, 56 MicH. L. REv. 1313 (1958); Note, 60 Mich. L. Rev. 98 (1961); cf. Note, Zoning-The Airport and the Land Surrounding It in the Jet Age, 48 KY. L.J. 273 (1960).

124328 U.S. 256 (1946).

$125 \mathrm{Id}$. at 265.

126 See, e.g., Davis v. United States, 295 F.2d 931 (Ct. Cl. 1961); Herring v. United States, 162 F. Supp. 769 (Ct. Cl. 1958); Highland Park, Inc. v. United States, 161 F. Supp. 597 (Ct. Cl. 1958); Hampstead Warehouse Corp. v. United States, 98 F. Supp. 572 (Ct. Cl. 1951).

127 Griggs v. County of Allegheny, $402 \mathrm{~Pa} .411,420,168$ A.2d 123, 127 (1961) (majority and dissenting opinions); Griggs v. Allegheny County, 369 U.S. 84, 90 (1962) (majority and dissenting ooinions). 
"approach areas"; to acquire necessary lands; and to abide by regulations of the Civil Aeronautics Administration. Defendant then leased the use of the airport to various airlines. The Supreme Court held that the county as "promoter, owner, and lessor of the airport"128 and as final arbiter of its location, was the "taker" and as such was liable to the owners for the value of the avigation easements over the property involved. There was no difference between the county's "responsibility for the air easements necessary for operation of the airport and its responsibility for the land on which the runways were built." 129 Congress gave to local authorities the duty to acquire air as well as surface easements.

Although the United States agrees to share from fifty to seventy-five per cent of the "allowable project costs,"130 there will still be a heavy financial burden on local communities to obtain necessary flight easements. As indicated previously, property values in an airport area increase greatly. 131 The date of valuation is thus extremely important. As the dissent in the Pennsylvania Supreme Court pointed out, one of the two questions in the case went to the date of taking. The date approved was when the airport opened for operation. 132 Other cases have held the date to be when "extensive use" of the airport began 133 and the date when the first jet flew over the subject property. 134 These formulations of the date all reach the same result: The theory is that once flights begin, market value is diminished as much as it ever will be. There is no "continuing" damage. 135

128369 U.S. at 89.

$129 \mathrm{Ibid}$. The Washington Supreme Court had previously reached the same result. Ackerman v. Port of Seattle, 55 Wash. 2d 400, 348 P.2d 664 (1960). The dissent in the Pennsylvania court was in agreement. $402 \mathrm{~Pa} .411,420,168 \mathrm{~A} .2 \mathrm{~d} \mathrm{123,127} \mathrm{(1961).} \mathrm{The} \mathrm{majority} \mathrm{of} \mathrm{the}$ Pennsylvania court suggested half-heartedly that the airlines themselves might be liable. Cheskov v. Port of Seattle, 55 Wash. 2d 416, 348 P.2d 673 (1960), a tort action against the Port and the airlines jointly, held that the statute of limitations barred the action. In strong dicta, however, it discarded liability of the airlines.

Mr. Justice Black, joined by Mr. Justice Frankfurter, dissented in the Supreme Court, arguing that the United States, rather than the local community, was the taker and should be the party required to compensate the property owners. The reasoning was that Congress had declared the airspace required for take-off and landing to be navigable airspace within the public domain; hence, Congress had already appropriated the property within which these easements were established and the local community should not be required to acquire the same easement. Compare Dunham, supra note 122, at 86, with Alfonso v. Hillsborough County Aviation Authority, 308 F.2d 724 (5th Cir, 1962).

13060 Stat. 175 (1946), 49 U.S.C. $\$ 1109$ (1958).

131 See note 51 supra.

$132402 \mathrm{~Pa}$. at $433,168 \mathrm{~A} .2 \mathrm{~d}$ at 134.

133 Ackerman v. Port of Seattle, 55 Wash. 2d 400, 348 P.2d 664 (1960).

${ }_{134}$ Highland Park, Inc. v. United States, 161 F. Supp. 597 (Ct. Cl. 1958). Plaintiff had argued for a valuation date in 1955, after which no financing could be obtained. The jets began using the airport in 1953. In the intervening period, property values had increased.

135 Cheskov v. Port of Seattle, 55 Wash. 2d 416, 348 P.2d 673 (1960). 
In Davis v. United States, 136 B-36 aircraft began flying over plaintiff's land in 1951. In 1957, the flight of B-52 jets began. Plaintiff sued for damages, claiming loss of market value from the 1957 flights. Defendant argued that the taking, if there was one, occurred in 1951, so that the action was barred by the statute of limitations. ${ }^{137}$ The court found, however, that although there was some diminution in value from the $1951 \mathrm{flight}$, it did not amount to a taking since the premises were still habitable. Not until the 1957 flights did the taking occur, and that was held to be the proper date of valuation.

Judge Whitaker, concurring, 138 argued that there had been a taking in 1951 ; that if compensation had been paid at that time, the resulting easement would have been for all flights, even if later-model planes caused a still greater diminution. Therefore he argued that the valuation date should be 1951, and that the government was not entitled to the lower award of the difference in value immediately before and after the advent of the jets, since the original government activities caused a lower value in 1957 than the property had in 1951. Plaintiff, however, had not claimed damage from 1951.

Judge Whitaker's argument, if applied in a case where a designation of blight has caused a diminution of property values even though the owner is not completely deprived of his property until eminent domain proceedings complete the process, would allow recovery of damages that were caused by the original designation. Unfortunately for property owners, the Causby rationale has not been employed except in the airspace situation. The court in Ackerman v. Port of Seattle139 said that "when private property rights are taken from the individual and are conferred upon the public for public use, eminent domain principles are applicable."140 This rule should apply in all areas where government is engaged in public improvements; it is illogical to limit it to airport problems. Perhaps, however, lower federal courts and state courts are heeding Mr. Justice Black's admonition that "old concepts of private ownership of land" should not be interjected into strictly modern situations.141 An admonition, however, cannot dissolve a constitutional requirement.

\section{InCRease in Market Value: Just Compensation to the Public}

The other aspect of the problems raised by the date of valuation is "just compensation" from the public's viewpoint. When property values are in-

136295 F.2d 931 (Ct. Cl. 1961).

137 Compare Ackerman v. Port of Seattle, 55 Wash. 2d 400, 348 P.2d 664 (1960), and Cheskov v. Port of Seattle, 55 Wash. 2d 416, 348 P.2d 673 (1960). These cases indicate that the statute of limitations will apply in a tort action, but not in a "taking" situation. Only the prescriptive period limits the latter.

138295 F.2d at 934. 13955 Wash. 2d 400, 348 P.2d 664 (1960).

140 Id. at 408,348 P.2d at 669.

141 United States v. Causby, 328 U.S. 356, 274 (1946) (dissenting opinion). 
creased because of governmental activity, does the "just compensation" standard require the public to pay for the amount of the increase traceable to its activity? The answer to this question depends on whether current activity induced the increase or whether the added value is the result of a prior improvement: In the former situation, the answer usually is "no"; in the latter, the answer is invariably "yes."

When property is designated for condemnation, or where there is knowledge of a planned public improvement but not of its exact location, "planning blight" is not always the result. Because of speculation either as to location or what the condemnor will be willing to pay, property values may rise.142 To exclude this speculative value from the condemnation award the courts must bypass strict application of the date of taking.

However, to say that value is to be fixed at the time of trial does not mean ... that the court must give consideration to enhancement resulting from construction or proposed construction of public improvements on the property subject to condemnation. To do so would allow speculative considerations to determine value and provide a windfall for the property owner. The courts will not sanction such considerations. ${ }^{143}$

The United States Supreme Court has furnished the test by which such speculative value may be excluded. Prior to 1943, the Court had articulated the rule that after the precise boundaries of an improvement were established,144 or after the exact outer limits of a project were known, 145 sales of vicinal property that was not within those boundaries could not be introduced as evidence of the value of the property to be taken for the improvement when the sales were made subsequent to the designation. The market prices of that property presumably reflect an increased value due to the contiguity of the improvement; the property that is thus sold is no longer similar to that which is to be taken.

In 1943, in United States $v$. Miller, 146 the Court enlarged the exclusionary rule. The location of a proposed improvement need no longer be conclusively established before exclusion of enhanced value is required. If property is "probably within" the scope of the project from the time the government was committed to it, although ultimately the property "might not" be taken, then any increase in value "due to" the proposed improvement must be excluded from the determination of just compensation. When this test is fulfilled, a

142 See notes 50, 51 supra and accompanying text. See also, United States v. Cooper, 277 F.2d 857 (5th Cir. 1960); San Diego Land \& Town Co. v. Neale, 78 Cal. 63, 20 Pac. 372 (1888); Yara Eng'r Corp. v. City of Newark, 136 N.J. Eq. 453, 42 A.2d 632 (1945).

143 Williams v. City \& County of Denver, 363 P.2d 171, 173 (Colo. 1961).

144 Kerr v. South Park Comm'rs, 117 U.S. 379 (1886).

145 Shoemaker v. United States, 147 U.S. 282 (1893).

146317 U.S. 369 (1943). See notes 98-103 supra and accompanying text, for a more complete discussion of the case. 
property owner is not entitled to speculate as to what the government will pay for his property; neither should he recover any value that the proposed improvement will add to adjacent property that is not taken. However, he still is entitled to any general increase in value not due to the taking. 147

Miller raises, but does not decide, major problems of burden of proof. Most

147 See, e.g., Scott v. United States, 146 F.2d 131 (5th Cir. 1944). Utah and Illinois are among the few states that do not accept the Miller rule. Weber Basin Water Conservancy Dist. v. Ward, 10 Utah 2d 29, 347 P.2d 862 (1959), explicitly rejected the rule. Illinois has not been as explicit-no case has been found that even cites Miller. In Cook v. South Park Comm'rs, 61 IIl. 115 (1871), the court held that it was not error to refuse to instruct that if lands adjacent to the improvement increased in value because of the project then the defendant should share in the increase, even though his property was being taken for the improvement. The case was affirmed in Kerr v. South Park Comm'rs, 117 U.S. 379 (1886). Seven years after Cook, however, in South Park Comm'rs v. Dunlevy, 91 Ill. 49 (1878), the Illinois court began to move away from the Cook holding. Dunlevy interpreted Cook as placing the date of taking, and hence of valuation, at the date the petition of condemnation is filed. Any increase in value after that date because of the prospective improvement should be ignored.

In 1896, the Illinois court made this statement: "The defendant in this case is entitled to the fair cash market value on the [date the petition is filed] regardless of the causes that gave it value at that time. If the jury believe... that the value of said property on that day was owing, in whole or in part, to the projection of the work upon the drainage canal, still the owner is entitled to the fair cash market value of the property as it then stood." Sanitary Dist. v. Loughran, 43 N.E. 359, 361 (1890). In Inter-State Water Co. v. Adkins, 327 IIl. 356,158 N.E. 685 (1927), the evidence concededly showed that the value of the subject property had increased as a result of the improvement for which it was taken, and that the taker contemplated taking the property even prior to beginning construction of the project. The court held, however, that the landowner was entitled to recover the value of his property as of the date the petition was filed, even though it had increased in "value by that time by reason of the fact that the improvement was constructed." Id. at 361, 158 N.E. at 687.

In Department of Pub. Works \& Bldgs. v. Finks, 10 I11. 2d 15, 139 N.E.2d 267 (1957), and City of Chicago v. Blanton, $15 \mathrm{Ml}$. 2d 198, 154, N.E.2d 242 (1958), the Illinois Supreme Court made statements that would be contrary to the above holdings, i.e., that a taking of property places it in a different category from neighboring property not taken, and that the latter will receive benefits or burdens from the condemnation not received by that taken. The issue in both cases, however, concerned admissibility of evidence of an offer to buy the subject property and a sale of neighboring property that took place after the condemnation petition was filed. The evidence was held inadmissible. Illinois at no time since Dunlevy has wavered from allowing evidence of similar property sales made prior to the date of taking.

Georgia also seems to reject Miller. In Housing Authority v. York, 126 S.E.2d 246, 247 (Ga. App. 1962), the following instruction was held not erroneous: "If at the time the property sought to be condemned was to be estimated, it was known or anticipated that certain improvements would be made in the locality where the property was situated, and this fact serves to enhance the market value of the property, the owner would be entitled to the actual market value as affected by the reason of the fact that it was known or anticipated that such improvements are to be made by the condemning party." But see, Housing Authority v. Hard, 128 S.E. 2d 533 (1962).

The following argument, which would probably prevail in Illinois, Utah and Georgia, was dismissed in State v. Cartwright, 351 S.W.2d 905, 906 (Tex. Civ. App. 1961): "[I]f [the condemnor] wanted to take this property back in 1954 when the project was started they had the same right to do it as they had to take it in 1958. But they didn't, and they couldn't sit down for four years in peace, and tie up this man's land for four years . . . and at that time try to roll back the price to 1954." Texas follows Miller. 
courts hold that the burden is on the government to show when the property was "probably within" the project area.148 There is no similar agreement on the question of who has the burden of proving enhancement, which is closely related to the question of how market value is to be proven. One of the primary means used to show market value is evidence of the prices at which similar property sold. For such evidence to be competent it must be shown that the other property was similar in location and use and that the sale was reasonably near in time. 149 Miller and some cases following it 150 excluded all sales made subsequent to the date when the property was probably within the proposed improvement. Such forthright exclusion would remove the burden from the condemnor. However, this probably needs to be qualified, since a property owner is still entitled to any general increase in property values. If counsel for the property owner could prove to the court that the subsequent sales prices did not reflect any project enhancement value, the evidence could probably be admitted. Otherwise, the date of valuation effectively would be the date when the property was probably within the scope of the improvement, rather than the date of taking. 151 Other courts unequivocally place the burden on the government to prove that a subsequent sale reflects enhancement due to the project.152 Subsequent sales are not inadmissible per se; the fact that they are subsequent to the date of probable inclusion goes only to their weight.

In 1949, the Supreme Court extended the Miller rule. During World War II, the United States requisitioned private tugs to aid wartime shipping. In United States $v$. Cors, 153 the Court held that in fixing compensation for a particular tug, the Court of Claims should determine whether prior government

148 See, e.g., United States v. Vilbig, 208 F.2d 663 (5th Cir. 1953); Iriarte v. United States, 157 F.2d 105 (Ist Cir. 1946); State v. Willey, 351 S.W.2d 900 (Tex. Civ. App. 1961). Cf. Cunningham v. United States, 270 F.2d 545 (4th Cir. 1959); John L. Roper Lumber Co. v. United States, 150 F.2d 329 (4th Cir. 1945). But see May v. City of Boston, 158 Mass. 21 (1893); Brubaker v. State, 27 Misc. 2d 458, 214 N.Y.S.2d 838 (Ct. Cl. 1961); Frego v. State, 25 Misc. 2d 1094, 209 N.Y.S.2d 699 (Ct. Cl. 1961); In the Matter of the City of New York (Lincoln Sq. Project), 22 Misc. 2d 619, 198 N.Y.S.2d 248 (Ct. Cl.), motion for rehearing denied, 23 Misc. 2d 690, 199 N.Y.S.2d 255 (Sup. Ct. 1960); Fitzgerald v. State, 10 Misc. 2d 1046, 173 N.Y.S.2d 661 (Ct. Cl. 1958).

149 See note 16 supra.

150 See, e.g., Cole v. Boston Edison Co., 338 Mass. 661, 157 N.E.2d 209 (1959); Brubaker v. State, 27 Misc. 2d 548, 214 N.Y.S.2d 838 (Ct. Cl. 1961); cf. Anderson v. United States, 179 F.2d 281 (5th Cir. 1950) (court took judicial notice of the fact that government projects generally tend to increase property values of land within the project).

151 Cf. Hance v. State Roads Comm'n, 221 Md. 164, 156 A.2d 644 (1959).

152 See, e.g., Iowa Redevelopment Co. v. State Highway Comm'n, 252 Ia. 978, 108 N.W.2d 487 (1961); State Highway Comm'n v. Stout, 134 So. 2d 467 (Miss. 1961). But cf. Redfield v. State Highway Comm'n, 252 Ia. 1256, 110 N.W.2d 397 (1961); IowA CoNST. art. I, § 18: The jury "shall not take into consideration any advantages that may result to said owner on account of the improvement for which it is taken."

153337 U.S. 325 (1949). 
acquisitions had so reduced the supply of available tugs that the lower supply, combined with continuing government demand, had in fact enhanced the market price. If so, the Court held that Miller covered the situation, and that the prior government effect on the market should be excluded in determining just compensation to the particular tug owner. 154 The case has been read merely as restating the already accepted rule155 that the particular need or demand of the condemnor must not be considered as a compensable component of market value.156 Although this restricted reading of Cors has been applied in cases involving real property, 157 the effect, if any, of prior government intervention in the market on the supply of property has not been considered in subsequent cases. Yet it is on the supply curve that part of the effect of prior government improvements is felt; as land is withdrawn from public use, other property necessarily becomes more valuable, not just because of the effect that the prior improvement may have on the desirability of the remaining property, but also because there is less land available.

The Miller rule continues to control. If the government is unable to prove that the subject property was probably within the proposed improvement, then the cases are in unanimous agreement that the owner is entitled to the value of his property, regardless of the causes of that value.158 Modern improvement projects, particularly urban redevelopment, are seldom planned or carried out all at once. As a result, the public may be forced to spend more in subsequent stages for property that is enhanced in value solely because a social need was met by previous improvements. This can be particularly disconcerting when subsequent improvements were within the original plan, but because of lack of funds only partial redevelopment was immediately accomplished. When the local public is able to obtain more funds, it will find that its dollar

154 In a vigorous dissent, Mr. Justice Frankfurter assailed the majority opinion on two grounds: Acquisition of the particular tug was not contemplated prior to its acquisition, so the case was not within the Miller rule; and it would be an impossible task for the Court of Claims to segregate different demand aspects of the market price. See Smith-Douglas Co. v. United States, 116 F. Supp. 570 (Ct. Cl. 1953) for an illustration of the difficulties involved. The majority opinion rested on the ground that prior case law supported its holding, although ostensibly it was construing a statute.

155 See note 33 supra.

156 See, e.g., United States v. Lambert, 146 F.2d 469 (2d Cir. 1945) (L. Hand, J.); Tigertail Quarries, Inc. v. United States, 143 F.2d 110 (5th Cir. 1944); United States v. Rayno, 136 F.2d 376 (1st Cir. 1943).

157 State Highway Comm'n v. Arnold, 218 Ore. 43, 341 P.2d 1089, rev'd on rehearing, 218 Ore. 43, 343 P.2d 1113 (1959) (condemnor will be excluded from the market whether or not it is the sole consumer).

158 Blas v. United States, 261 F.2d 636 (9th Cir. 1959); Iriarte v. United States, 157 F.2d 105 (1st Cir. 1946); In the Matter of the City of New York (Lincoln Sq. Project), 22 Misc. 2d 619, 198 N.Y.S.2d 248, motion for rehearing denied, 23 Misc. 2d 690, 199 N.Y.S.2d 225 (Sup. Ct. 1960); City of Dallas v. Shackelford, 145 Tex. 528, 200 S.W.2d 869 (1947); State v. Willey 351 S.W.2d 900 (Tex. Civ. App. 1961); cf. Andrews v. State, 9 N.Y.2d 606, 176 N.E.2d 42, 43 (1961) (majority and dissenting opinions). 
cannot buy as much property to improve as it would have if the additional appropriation had been available in the beginning.

While the rule may be harsh, it may be desirable to allow property owners to reap this benefit at the expense of the public, at least in the context of urban renewal. The cost of immediate and total acquisition in a redevelopment area would be prohibitive. 159 Consequently, to aid in renewal attempts, policy is designed to encourage as much private participation as possible. This comes under the rubric of conservation and rehabilitation of existing property. 160 If a rule were devised to prevent private property owners from realizing the benefits of increased value due to public participation, the objective of private participation would be endangered.161

The experience of Great Britain is pertinent at this point. ${ }^{162}$ To understand the English solution it is necessary briefly to trace its statutory history. The Acquisition of Land Act of 1919163 determined market value to be the standard of compensation for government acquisition of private lands. The Town and Country Planning Acts of 1925164 and 1932165 added to this standard of compensation: If a planning scheme diminished the value of a man's property (injurious affection), he was to be compensated therefor; if, on the other hand, property value was increased by the scheme, the local authority was entitled to a recoupment of a percentage of the betterment that accrued. "Compensation and betterment had, by the early years of the war, become the Siamese twins of planning control."166

Recoupment, however, proved virtually impossible. In 1942, the Uthwatt

159 Note, Urban Renewal: Problems of Eliminating and Preventing Urban Deterioration, 72 HARv. L. Rev. 504, 539 (1959). But see Cox, Urban Renewal-The Viewpoint From City Hall, 1960 PLANNING 116.

160 See Osgood \& Zwerner, Rehabilitation and Conservation, 25 LAW \& CONTEMP. ProB. 705 (1960); Slayton, Conservation of Existing Housing, 20 LAW \& CONTEMP. PROB. 436 (1955).

161 See notes 175-84 infra, and accompanying text, for reference to the English experience.

162 A discussion of English law, as it relates to the problems with which this comment is concerned must keep in mind two basic facts: In England there is no constitutional requirement of "just compensation;" the result has been a much more liberal attitude toward allowing legislative interference. "Just as the state can by statute modify the common law right to compensation where property is taken, so it can provide in a suitable case for the deficiency of the common law where injury is caused by the abrogation of rights of property." Leach, Planning Control Under Pressure, 1960 J. PLAN. \& Prop. L. 237, 240. Secondly, the English are involved in a complex and comprehensive planning scheme that covers the entire country. See generally, HeAP, AN OUtuINe OF PlanNING LAW, ch. 4-6 (3d ed. 1960). However, in pursuing, and perhaps as a result of comprehensive planning, the English have come closer to a reasonable standard of just compensation than have the courts in the United States where the requirement is explicit.

$1639 \& 10 \mathrm{Geo} .5$, c. 35 .

16415 Geo. 5 , c. 16.

$16522 \& 23 \mathrm{Geo} .5$, c. 48.

166 Heap, Compensation for Compulsory Purchase and Planning Restrictions, $1958 \mathrm{~J}$. PLAN. \& PROP. L. 779, 781. 
Report ${ }^{167}$ recommended substantial policy changes. The result was the Town and Country Planning Act of 1947.168 This was the beginning and basis of postwar English planning legislation. The most striking characteristic of the act is its comprehensive approach to planning. Flexible plans were to be drawn that would guide decisions as to development in cities and virtually prevent development in country green-belt areas. The revolutionary means to achieve the ends of planning was in essence to expropriate for the nation the "development value" of all private property. Any subsequent compulsory acquisition by government was to be paid for at the "existing use value" as of 1947. Citizens could no longer change the existing use of their property without approval of the local planning board.169 The "fund" was established to allow payment for any of the claims that could be made for loss of this development value. If a property owner subsequently acquired permission to develop his property, that is, to change its use, he was to pay to the government a "development charge"170 that was commensurate with the increased value of the property due to the planning permission.

The planning provisions of the 1947 act concededly worked well.171 Diffculty developed, however, with the compensation provisions. The act hoped to "freeze" the market value of property: Because a purchaser knew he would have to pay a development charge if he desired to develop the land he would pay only its exiting use value.172 What occurred, however, was that sellers were unwilling to accept only the existing use value; purchasers were forced to pay the full market value of the property, plus a development charge. In 1953, therefore, the development charge was abolished.173

The compensation provisions of the 1947 Act were supplanted by the Town and Country Planning Act of 1954.174 When the development charge was abolished, development value was restored to the land. In a limited number of cases compensation for planning restrictions was recoverable, but at development values as they existed in 1947.175 Thus, no development value was (1942).

167 Report of the Expert Committee on Compensation and Betterment, CMD. No. 6386

16810 \& 11 Geo. 6, c. 51. See generally, Heap, op. cit. supra note 162; Mandelker, Notes from the English: Compensation in Town and Country Planning, 49 CALIF. L. REv. 699, 70923 (1961).

169 In certain cases, if permission to develop was refused, the property owner could force the government to purchase his property, giving him, in effect, the power of reverse condemnation. $\$ 19$ of the 1947 Act. See Mandelker, supra note 168, at 711-23.

170 Town and Country Planning Act, 1947, 10 \& 11 Geo. 6, c. 5, Part IV.

171 Heap, supra note 166, at 783; Heap, Planning Legislation at Home and Abroad, 1961

J. PLAN. \& PROP. L. 650, 652.

172 Heap, supra note 166, at 784; Leach, supra note 162, at 241.

173 Town and Country Planning Act, 1953, 1 \& 2 Eliz. 2, c. 16.

1742 \& 3 Eliz. 2, c. 72. See Mandelker, supra note 168, at 723-36.

1752 \& 3 Eliz. 2, c. $72, \S \S 20-24$. 
recognized in the provisions relating to compulsory purchases. 176 As a result, the difference between compensation for government acquisition and the price of substitute land in the private market tended to grow larger; it resulted in what became known as the "two codes of compensation." 177 The divergence also resulted in profits to the government if property was resold to private developers.

Popular dissatisfaction with this situation was widespread.178 The result was the Town and Country Planning Act of 1959.179 The primary change was a "return to market value" as the standard of compensation for compulsory acquisitions. 180 There are, however, certain modifications on a strict market value standard: (1) No increase in value will be compensated if it was due to the development scheme that gave rise to the government's acquisition;181 (2) if the acquisition is only a "partial taking"' benefits to the remaining portion may be set off against the award for the tract taken;182 (3) trade losses

176 Leach, supra note 162, at 245-46.

177 Heap, supra note 166, at 788.

178 Id. at 789; Leach, supra note 162 at 247. But see Krasnowiecki \& Paul, The Preservation of Open Space in Metropolitan Areas, 110 U. PA. L. Rev. 179, 198-99 (1961); the authors advocate an approach similar to the one discarded by the 1959 Town and Country Planning Act.

1797 \& 8 Eliz. 2 , c. 53.

180 HEAP, op. cit. supra note 162, at 168; Heap, Market Value Compensation for Compulsory Purchase, 1958 J. PLAN. \& PROP. L. 853.

181 Town and Country Act, 1959, 7 \& 8 Eliz. 2, c. 53, § 9(2). See Leach, Compensation for Compulsory Acquisition of Land: Town and Country Planning Act, 1959-II, 1959 J. PLAN. \& PROP. L. 549, 553.

182 Town and Country Planning Act, 1959, 7 \& 8 Eliz. 2, c. 53, §9(3). A "partial taking" is one where only a portion of the owner's property is taken for a public improvement. Generaily, such a situation will predominate more in improvements that involve streets or highways. Rarely will a partial taking occur in urban redevelopment, since entire areas are there involved. In the United States the same rules of valuation will apply to the portion taken as when an entire parcel is condemned. People v. Schultz Co., 123 Cal. App. 2d 925, 268 P.2d 117 (1954); Concordia Cemetery Ass'n v. Minnesota \& N.W. Ry., 121 Ill. 199, 12 N.E. 536 (1887). The peculiar aspect of the partial taking relates to that portion which is not taken. It has long been held that damages and benefits to the remaining portion are relevant to compensation for the tract taken. Commonwealth v. Coombs, 2 Mass. 489 (1807). If the remainder has been damaged, the amount of the damages will be added to the award for the portion taken. Some courts hold that for damage to be compensable, it must be caused by activity of the condemnor that takes place on that portion of the tract taken; if the damage is caused by the improvement for which the property was taken, but not by an activity on the portion taken, no damages are allowed. See, e.g., United States v. Cooperman, 263 F.2d 331 (2d Cir. 1959) (per curiam); People ex rel. Department of Pub. Works v. Symons, 54 Cal. 2d 855, 9 Cal. Rptr. 363, 357 P.2d 451 (1960); City of Crookston v. Erickson, 244 Minn. 321, 69 N.W.2d 909 (1955). Others hold that any damage is recoverable, so long as it results from the improvement for which the property was taken. See, e.g., State Highway Comm'n v. Bailey, 212 Ore. 261, 319 P.2d 906 (1957); State Highway Comm'n v. Bloom, 77 S.D. 452,93 N.W.2d 572 (1958). Compare Hanson v. City of Omaha, 157 Neb. 403, 59 N.W. 2d 622 (1953). If it also has been benefitted, most courts allow "special" benefits to be set off against the damage incurred (3 NICHOLs $\S 8.6205$ (3d ed. 1950); United States v. 2,477.79 Acres of Land, 259 F.2d 23 (5th Cir. 1958)) and some allow a set- 
and costs of removal will in certain instances be compensable;183 (4) in various circumstances a property owner is given five years to claim additional compensation because unforeseen planning possibilities added value to the property. 184

Thus, the English were forced by experience to discard a theory that appeared perfect on paper. There was a return to the market value standard in order to achieve the cooperation and satisfaction of the populace. As indi-

off of general benefits, which in effect means any factor causing a higher market value. People v. Schultz Co., 123 Cal. App. 2d 925, 268 P.2d 117 (1954); Dougherty County v. Pylant, 104 Ga. App. 468, 122 S.E.2d 117 (1961); Sanitary Dist. v. Loughran, 160 Ill. 362, 43 N.E. 359 (1896). The measure of compensation is the same in either situation: The difference in the market value of the remaining tract immediately before the taking and its value immediately after the taking, thus accounting for the effect of the improvement both as to damages and benefits. It would seem that damages caused by the improvement are much more easily recoverable in a partial taking than when an entire tract is taken. Compare Bauman v. Ross, 167 U.S. 548 (1897) and Department of Pub. Works \& Bldgs. v. Wolf, 414 III. 386, 111 N.E.2d 322 (1953), with Monongahela Nav. Co. v. United States, 148 U.S. 312 (1893).

The most controversial question, and the most significant with regard to the vast increase in the use of eminent domain, is whether benefits to the remainder that exceed damages may be set off against the award for the portion taken. The federal rule was announced in Bauman v. Ross, 167 U.S. 548, 574-75 (1897): "[W] hen part only of a parcel of land is taken for a highway, the value of that part is not the sole measure of the compensation or damages to be paid to the owner; but the incidental injury or benefit to the part not taken is also to be considered. When the part not taken is left in such shape or condition, as to be in itself of less value than before, the owner is entitled to additional damages on that account. When on the other hand, the part which he retains is specially and directly increased in value by the public improvement, the damages to the whole parcel by the appropriation of part of it are lessened. If, for example, by the widening of a street, the part which lies next to the street, being the most valuable part of the land, is taken for the public use, and what was before in the rear becomes the front part, and upon a wider street, and thereby of greater value than the whole was before, it is neither just in itself, nor required by the Constitution, that the owner should be entitled both to receive the full value of the part taken, considered as front land, and to retain the increase in value of the back land, which has been made front land by the same taking."

Mr. Nichols indicates that most jurisdictions increasingly have moved away from this rule and hold that benefits to the remainder cannot be set off against the award for the portion taken. 3 NicHOLs, at $\$ 8.6206$. At the same time, the tendency is to allow general benefits to be set off against damages to the remainder. 3 id. at $\$ 8.6205$. The Batuman rule, however, remains the federal rule. See Richard v. United States, 282 F.2d 901 (Ct. Cl. 1960). Because just compensation is said to be what the owner has lost, if the remainder in a partial taking is worth more than the previous market value of the entire tract the owner has lost nothing. The condemnor is forced to pay "compensation" when there has been no loss, indeed when its own activities have caused an over-all increase. The property owner in effect thus receives double compensation. This certainly encroaches on the rule that "just compensation" must be just to the public as well as the individual. And it is inconsistent with the Miller rule, which purportedly is followed in most jurisdictions.

183 Town and Country Planning Act, 1959, 7 \& 8 Eliz. 2, c. 53, §13.

184 Town and Country Planning Act, 1959, 7 \& 8 Eliz. 2, c. 53, §18. A final modification provides that any diminution in value which was due to the threat of compulsory acquisition shall be disregarded. Town and Country Planning Act, supra, §9(6). See text accompanying note 118 supra. 
cated by the first modification of the 1959 Act, the English rule is now approximately the same as the Miller rule. If property is condemned after its value is enhanced by a previous improvement, either because of proximity or the supply and demand function, and the property was not included in the plans for the prior improvement, then the owner is entitled to recover the value as enhanced. Even if this rule is accepted, however, the results of two recent California cases are totally unnecessary. In County of Los Angeles $v$. $H o,, 185$ the county and city were responsible for different buildings in a new municipal civic center. The court held that it was not error to consider enhancement caused by the city's improvements in a condemnation proceeding by the county, since negotiations between the city and county were only "preliminary and contingent," and no integrated plan had been consummated. A similar situation was presented in City of San Diego v. Boggeln.186 There, the city instituted condemnation proceedings to provide a new park. The United States at the same time was engaged in construction of a flood control channel in the area. The court held that it was not error in the city's condemnation proceeding to consider values as enhanced by the federal improvements because benefits to property within the city park project were only a portion of the total benefits from the federal project, and that the question of whether the park was an integral part of the total project was for the jury to answer.

The teaching of Hoe and Boggeln is that in order to save the taxpayers' money the same governmental body must construct the entire improvement. If two separate governmental units combine their resources to benefit the public, they in effect must work so closely as to form one consolidated unit. If they do not do so, the result of their joint efforts will be to benefit particular individuals at the expense of the public. The concept of "just compensation" should not require this result. The property owner has "lost" nothing merely because one branch of government did not attempt to construct an entire project. When two different branches of government agree to work together, rather than at cross purposes, the public as a whole should benefit from the happy circumstance. That there is too seldom such agreement need not require a court to allow the jury just one more excuse for helping the unfortunate individual whose property is taken.187

185138 Cal. App. 2d 74, 291 P.2d 98 (1955).

186164 Cal. App. $2 d$ 1, 330 P.2d 74 (1958).

187 In State v. Arnold, 218 Ore. 43, 341 P.2d 1089, modified on motion to reconsider, 218 Ore. 82, 343 P.2d 1113 (1959), the court held that the condemnor's demand for the property must be completely disregarded. One of its reasons for so doing was based on a quote from Graubart, Theory Versus Practice in the Trial of Condemnation Cases, 26 PA. BAR Ass'N Q. 36 (1954): "We are trying a gteat many condemnation cases in Pennsylvania due to the increasing need of the Commonwealth, municipalities, authorities and commissions to take property for public uses. In these trials, juries usually return large verdicts, often twice as much as the property is worth." See also Heaney, $A$ Comparison of Statutory and Court- 


\section{Conclusion}

The English, without a requirement of just compensation, have done by statute what United States courts have not as yet been able to do without a statute, but with an explicit constitutional requirement of just compensation. Although there is no dearth of arguments in favor of compensation for planning blight, state courts seem unable to fashion a "just" remedy. Unless and until the Supreme Court speaks, the judicial situation will probably remain as it is.

Statutory relief, however, should be available. Since compensation for blight is not a limit on compensation, the legislature may expand the concept of just compensation without infringing on the powers and duties of the judiciary. 188 An appropriate statute would have to provide for full realization of general increases in market value up to the date of taking. ${ }^{189}$ It could either require earlier condemnation proceedings or exclude decreases caused by the proposed improvement, with full recognition of the factors that cause blight, from the market value at the date of taking. Condemning authorities would probably disapprove of the first alternative on the ground that time is necessary to perfect their plans. The second alternative, as the Town and Country Planning Act of 1959 indicates, is not beyond the realm of possibility. Add to this a provision for reverse eminent domain 190 and a solution to the problems of planning blight is at hand.

The solution to the public's problems is not as easy, and this writer has no easy solutions. The English experience shows that the practical difficulty of obtaining the co-operation of the public will be encountered. The United States would experience the additional constitutional problem previously discussed: the omnipresent police power-eminent domain dichotomy.

Made Rules of Eminent Domain Valuation with Actual Practices, in LAND ACQUISIrION1959, at 105 (Highway Research Board, Bull. No. 232, 1959) (the author contends that appraisers take account of damages which the law says are non-compensable, that excessive political influence is exerted in condemnation cases, and that rules of evidence virtually are not enforced in the proceedings, thus leading to awards that are much larger than can be justified).

188 Nichols v. Commonwealth, 331 Mass. 581, 121 N.E.2d 56 (1954); Connor v. Metropolitan Dist. Water Comm'n, 314 Mass. 33, 49 N.E.2d 593 (1943).

189 See State v. Griggs, 89 Ariz. 70, 358 P.2d 174 (1960); Opelousas G. \& N.E. Ry. v. Saint Landry Cotton Oil Co., 118 La. 290, 42 So. 940 (1907); City of St. Louis v. International Harvester Co., 350 S.W.2d 782 (Mo. 1961). Cf. United States v. Miller, 317 U.S. 369 (1943), and the official map cases.

190 See, e.g., Wis. STAT. $\$ 32.10$ (Supp. 1962). 